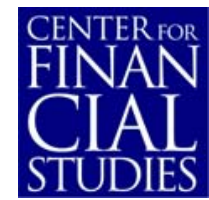

No. $2007 / 05$

\title{
Three Great American Disinflations
}

Michael Bordo, Christopher Erceg,

Andrew Levin, and Ryan Michaels 


\section{Center for Financial Studies}

The Center for Financial Studies is a nonprofit research organization, supported by an association of more than 120 banks, insurance companies, industrial corporations and public institutions. Established in 1968 and closely affiliated with the University of Frankfurt, it provides a strong link between the financial community and academia.

The CFS Working Paper Series presents the result of scientific research on selected topics in the field of money, banking and finance. This paper was presented at the International Research Forum on Monetary Policy 2006 which was held at the Federal Reserve Board in Washington DC and jointly organized by the Federal Reserve Board, the European Central Bank, the BMW Center for German and European Studies at Georgetown University and the Center for Financial Studies at Frankfurt University.

If you would like to know more about the Center for Financial Studies, please let us know of your interest.

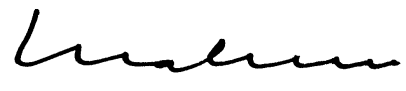

Prof. Dr. Jan Pieter Krahnen

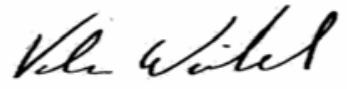

Prof. Volker Wieland, Ph.D. 


\title{
Three Great American Disinflations*
}

\author{
Michael Bordo ${ }^{1}$, Christopher Erceg ${ }^{2}$, \\ Andrew Levin ${ }^{3}$, and Ryan Michaels ${ }^{4}$
}

November 24, 2006

\begin{abstract}
:
In this paper, we examine three famous episodes of deliberate deflation (or disinflation) in U.S. history, including episodes following the Civil War, World War I, and the Volcker disinflation of the early 1980s. These episodes were associated with widely divergent effects on the real economy, which we attribute both to differences in the policy actions undertaken, and to the transparency and credibility of the monetary authorities. We attempt to account for the salient features of each episode within the context of a stylized DSGE model. Our model simulations indicate how a more predictable policy of gradual deflation could have helped avoid the sharp post-WWI depression. But our analysis also suggests that the strong argument for gradualism under a transparent monetary regime becomes less persuasive if the monetary authority lacks credibility; in this case, an aggressive policy stance (as under Volcker) can play a useful signalling role by making a policy shift more apparent to private agents.
\end{abstract}

JEL Classification: E31, E32, E52

Keywords: DSGE Model, Credibility, Deflation

\footnotetext{
* The views expressed in this paper are solely the responsibility of the authors and should not be interpreted as reflecting the views of the Board of Governors of the Federal Reserve System or of any other person associated with the Federal Reserve System. We thank Francois Velde (our discussant), Anna Schwartz and Thomas Sargent for helpful comments and suggestions, as well as seminar participants at Columbia University, the Federal Reserve Board, Harvard University, and at an NBER conference honoring Anna Schwartz.

1 Rutgers University

2 Corresponding author: Federal Reserve Board, $20^{\text {th }}$ and C Street, N.W. Washington, D.C. 20551, Phone: +1202 452-2575, Email: Christopher.Erceg@frb.gov

3 Federal Reserve Board

4 University of Michigan
} 


\section{Introduction*}

Since at least the time of David Hume (1752) in the mid-18th century, it has been recognized that episodes of deflation or disinflation may have costly implications for the real economy, and much attention has been devoted to assessing how policy should be conducted to reduce such costs. The interest of prominent classical economists in these questions, including of Hume, Thornton, and Ricardo, ${ }^{1}$ was spurred by practical policy debates about how to return to the gold standard following episodes of pronounced wartime inflation. Drawing on limited empirical evidence, these authors tried to identify factors that contributed to the real cost of deflation, including factors controlled by policy. They advocated that a deflation should be implemented gradually, if at all; in a similar vein a century later, Keynes (1923) and Irving Fisher (1920) discussed the dangers of trying to quickly reverse the large runup in prices that occurred during World War I and its aftermath.

While the modern literature has provided substantial empirical evidence to support the case that deflations or disinflations are often quite costly (Gordon 1982 and Ball 1994), there is less agreement about the underlying factors that may have contributed to high real costs in some episodes, or that might explain pronounced differences in costs across episodes. Indeed, disagreement about the factors principally responsible for influencing the costs of disinflation helped fuel contentious debates about the appropriate way to reduce inflation during the 1970s and early 1980s. Most policymakers and academics recommended a policy of gradualism, reflecting their belief that the costs of disinflation were largely due to structural persistence in wage or pricesetting. Others recommended aggressive monetary tightening, on the grounds that the credibility of monetary policy in the 1970s had sunk too low for gradualism to be a viable approach to

The views expressed in this paper are solely the responsibility of the authors and should not be interpreted as reflecting the views of the Board of Governors of the Federal Reserve System or of any other person associated with the Federal Reserve System. We thank Francois Velde (our discussant), Anna Schwartz and Thomas Sargent for helpful comments and suggestions, as well as seminar participants at Columbia University, the Federal Reserve Board, Harvard University, and at an NBER conference honoring Anna Schwartz.

${ }^{1}$ Humphrey (2004) provides an excellent survey of the views of the leading classical economists on deflation and the challenges it presented to policy. 
permanently reducing inflation.

In this paper, we examine three famous episodes of deliberate deflation or disinflation in U.S. monetary history, including the post-Civil War Resumption period of 1866-79; the post World War I deflation of 1920-22; and the Volcker disinflation of $1979-83 .{ }^{2} \quad$ One goal of our paper is to use these episodes to illuminate the factors that influence the costs of monetary contractions. These episodes provide a fascinating laboratory for this analysis, insofar as they exhibit sharp differences in the policy actions undertaken, in the credibility and transparency of the policies, and in the ultimate effects on inflation and output. Our second objective is to evaluate the ability of a variant of the New Keynesian model that has performed well in fitting certain features of post-war U.S. data to account for these important historical episodes.

Our paper begins by providing a historical overview of each of these episodes. As seen in Figure 1, the 30 percent price decline that occurred during the Resumption period was stretched out over more than a decade. We argue that the highly transparent policy objective (of returning to the Gold Standard at the pre-war parity), the credible nature of the authorities' commitment, and gradual implementation of the policy helped ease disruptive effects on the real economy: in fact, output growth averaged a robust $4-5$ percent per year over the course of the decade. By contrast, while prices also fell 25-30 percent from their peak during the deflation that began in mid-1920 - as shown in Figure 3 - the price decline was accompanied by a transient but extremely sharp decline in real activity. We interpret the large output losses as attributable to the Federal Reserve's abrupt departure from the expansionary policies that had prevailed until early 1920; fortunately, because the ultimate objective of policy was clear (reducing prices enough to raise gold reserves), the real effects were fairly transient. Finally, the Volcker disinflation succeeded in reducing inflation from double digit rates in the late 1970s to a steady 4 percent by roughly 1983, though at the cost of a severe and prolonged recession (see Figure 4). We argue that

\footnotetext{
2 Thus, we do not consider the Great Depression in our analysis, since it does not appear to fall under the category of a deliberate deflation.
} 
the substantial costs of this episode on the real economy reflected the interplay both of nominal rigidities, and the lack of policy credibility following the unstable monetary environment of the previous 15 years.

We next analyze some fairly novel datasets that attempt to measure policy predictability during each of the three episodes in order to quantify the extent to which each deflation was anticipated by economic agents. For the two earlier periods, we construct a proxy for price level forecast errors by using commodity futures data and realized spot prices. While these commodity price forecast errors provide very imperfect measures of errors in forecasting the general price level, we believe that they provide useful characterizations of the level of policy uncertainty during each period: in particular, the commodity price forecast errors were several times larger in the 1920 s than in the 1870 s, and exhibited substantially greater persistence. This pattern seems to strongly confirm other evidence on policy predictability during each episode taken from bond yields, contemporary narrative accounts, and informal surveys. Finally, for the Volcker period, we utilize direct measures of survey expectations on inflation to construct inflation forecast errors (following Erceg and Levin 2003), and show that forecast errors were large and extremely persistent, suggesting a high degree of uncertainty about the Federal Reserve's policy objectives.

We then examine whether a relatively standard DGSE model is capable of accounting for these different episodes. The model that we employ is a slightly simplified version of the models used by Christiano, Eichenbaum, and Evans (2005) and Smets and Wouters (2003). Thus, our model incorporates Calvo-Yun staggered contracts to rationalize inertia in both prices and wages, and incorporates various real rigidities including investment adjustment costs and habit persistence in consumption. The structure of the model is identical across periods, aside from the characterization of monetary policy. In particular, we assume that the monetary authority targets the price level in the two earlier episodes, consistent with the authorities desire to reinstate or support the Gold standard; by contrast, we assume that the Federal Reserve followed a Taylorstyle interest rate reaction function in the Volcker period, responding to the difference between 
inflation and its target value. Moreover, we assume that agents had imperfect information about the Federal Reserve's inflation target during the Volcker episode, and had to infer the underlying target through solving a signal extraction problem.

We find that our model performs remarkably well in accounting for each of the three episodes. Notably, the model is able to track the sharp but transient decline in output during the 1920s, as well as the size and persistence of the output decline under Volcker. Our ability to fit the timing of the downturn during the Volcker period represents a significant improvement over Erceg and Levin (2003), who found using a standard Q-theory version of capital adjustment costs that their model implied far too rapid an output decline. More generally, we interpret the overall success of our model in fitting these disparate episodes as reflecting favorably on the ability of the New Keynesian model - augmented with some of the dynamic complications suggested in the recent literature - to fit important business cycle facts. However, one important twist is our emphasis on the role of incomplete information in accounting for the range of outcomes.

Finally, we use counterfactual simulations of our model to evaluate the consequences of alternative strategies for implementing a new nominal target (i.e., either a lower price level, or a lower inflation rate). We find that under a highly transparent policy regime, a new nominal target can be achieved with with minimal fallout on the real economy, provided the implementation occurs over a period of at least 3-4 years. In this vein, we use model simulations to show that a more predictable policy of gradual deflation - as occurred in the 1870 s - could have helped avoid the sharp post-WWI downturn. However, our analysis of the Volcker period emphasizes that the strong argument for gradualism under a transparent and credible monetary regime becomes less persuasive if the monetary regime lacks credibility. In this lower credibility case, an aggressive policy stance can play an important signalling role insofar as it makes a policy shift - such as a reduction in the inflation target - more apparent to private agents. Because inflation expectations adjust more rapidly than under a gradualist policy stance, output can rebound more quickly.

The rest of the paper proceeds as follows. Section 2 describes the three episodes, while Section 
3 examines empirical evidence on the evolution of expectations during each episode. Section 4 outlines the model, and Section 5 describes the calibration. Section 6 matches the model to the salient features of the three episodes, and considers counterfactual policy experiments. Section 8 concludes.

\section{Historical Background}

\subsection{Post-Civil War (1866-1879)}

Given the high cost of financing the Civil War, the U.S. government suspended gold convertibility in 1862 and issued fiat money ("greenbacks"). The monetary base expanded dramatically in the subsequent two years, precipitating a sharp decline in the value of greenbacks relative to gold. The dollar price of a standard ounce of gold rose from its official price of $\$ 20.67$ that had prevailed since 1834 to over $\$ 40$ by 1864 (the lower panel of Figure 1 shows an index of the greenback price of gold relative to its official price of $\$ 20.67$ ). Despite some retracing in the late stages of the war, the dollar price of gold remained about 50 percent above its official price by the cessation of hostilities in mid-1865.

Following the war, there was widespread support for reverting to a specie standard at the pre-war parity. In the parlance of the period, this meant eliminating the "gold premium," the difference between the market price of gold and the official price. Using simple quantity theory reasoning, policymakers regarded monetary tightening as the appropriate instrument for achieving this objective: if the overall price level fell sufficiently, the dollar price of gold would drop, and the gold premium eventually disappear. Accordingly, Congress passed the Contraction Act in April 1866, with the backing of President Johnson. This act instructed the U.S. Treasury - the effective monetary authority during that period - to retire the supply of greenbacks. Given initial public support for a quick return to convertibility, Treasury proceeded aggressively, reducing the monetary base about 20 percent between 1865 and 1867 . However, the associated price deflation caused real activity to contract significantly, with certain sectors experiencing disproportionate 
effects (e.g., heavily leveraged farmers). Thus, Congress and President Johnson were forced to temporarily suspend monetary tightening in the face of strong public protest (Friedman and Schwartz, 1963, pgs. 44-45).

President Grant promised to renew the march toward resumption when he delivered his first inaugural in March 1869, but with the important difference that the deflation would be much more gradual. By June 1869, the president received key legislative support with the passage of the Public Credit Act, which pledged that the Federal Government would repay its debt in specie within ten years. The long timeframe reflected the new political imperative of a gradualist approach. With further monetary contraction deemed infeasible, supporters of resumption planned to keep the money stock roughly constant, and allow prices to fall slowly as the economy expanded. This philosophy helped guide legislation, and in turn the U.S. Treasury's operational procedures for conducting monetary policy. Thus, Treasury policy kept the monetary base fairly constant through most of the 1870s, offsetting the issuance of National Bank notes with the retirement of Greenbacks. Its ability to adhere to this policy was facilitated by the passage of the Resumption Act in 1875, which sealed January 1, 1879 as the date of resumption of convertibility, and by the election of the hard-money Republican candidate Rutherford Hayes in the 1876 election. As seen in Figure 1, these policies succeeded in producing a fairly smooth and continuous decline in the aggregate price level, and allowed the authorities to comfortably meet the January 1879 deadline for the resumption of specie payments. Remarkably, notwithstanding the pronounced slowing in activity following the worldwide financial panic of 1873, real output growth was very robust over the decade, averaging nearly 4-5 percent per year.

This strong economic growth in the face of substantial deflation seems to have been made possible because of the fairly predictable nature of the price decline between the passage of the Public Credit Act in 1869 and resumption a decade later. Two factors played an important role in making the price decline predictable. First, the ultimate objective of restoring the gold price to its official (pre-war) level was highly credible. This served to anchor expectations about the long- 
run expected price level within a fairly narrow range, so that uncertainty about future price level mainly reflected uncertainty about the path of the real value of gold (in terms of goods). Second, it was clear after 1868 that the target of restoring convertibility would be achieved gradually. As discussed above, there was little support in Congress for returning to the rapid pace of monetary contraction that followed the Civil War.

Our contention that the policy of restoring gold convertibility at the official pre-war price was highly credible may seem difficult to reconcile with the political agitation in favor of Greenbacks that would seem a salient feature of the 1870s. But support for the Gold standard - both within the U.S. government, and the public at large - remained extremely strong in the post-Civil War period, so that the net effect of the political agitation was simply to graduate progress towards convertibility. 3 This support for resumption stemmed in part from historical precedent: the United States had been on a specie standard for almost its entire history, dating to the passage of the Coinage Act of 1792. It also reflected deeply-seated views about how a specie standard protected private property rights against unjust seizure, which was regarded as a moral and political imperative. Finally, adhering to a specie standard was regarded as important for securing full membership in the international community (given it was the practice in all major industrialized countries), and for deriving the commercial benefits attributed to fixed exchange rates.

Overall, this analysis suggests that it is appropriate to characterize the U.S. deflation experience over at least the 1869-79 period as one in which both the final objective of policy was transparent and credible, and which implied a fairly clear path for the overall price level. There was admittedly some uncertainty about what the target for the dollar price of gold implied for the long-run price level, i.e., for how much price deflation would ultimately have to take place. However, while the real price of gold rose through the 1870 s, it seems unlikely that this slow and steady rise

\footnotetext{
3 Indeed, the restoration of specie convertibility was supported by all three branches of government. It had the enthusiastic backing of the three successive Republican presidents who held office during the period (Johnson, Grant, and Hayes), and, through its decisions, the indirect support of the Supreme Court. While there was less unanimity in Congress, especially after the 1873 Panic, the debate hinged more on the appropriate speed of restoring convertibility at the official price, rather than on the ultimate goal.
} 
significantly exacerbated the problem faced by private agents of making price-level forecasts to set the terms of multiperiod contracts. Thus, private agents were able to set contracts (including labor and financial contracts) in an environment of fairly predictable deflation, which minimized the potentially adverse consequences of deflation on real activity.

\subsection{Post WWI (1919-1922)}

The U.S. government suspended the gold standard de facto shortly after it entered World War I and began an enormous arms build-up that fueled inflation. President Wilson ordered the suspension and placed an embargo on the export of gold in order to protect the country's stock. In the absence of the embargo, high inflation likely would have triggered large outflows of gold: GNP prices rose almost 40 percent while the U.S. was at war, which was equal to the cumulative increase in prices observed in the 15 years earlier. Wartime inflation had its roots in an almost 20-fold increase in federal government expenditure from the time the U.S. entered the war in April 1917 to the armistice in November 1918 (see Firestone, 1960, Table X). Twenty percent of this increase was financed by money creation by the country's young central bank, the Federal Reserve System (Rockoff, 2004).

When the war ended, the embargo was lifted, and Treasury and the Federal Reserve had to negotiate monetary policy in order to protect the Gold standard. ${ }^{4}$ The Federal Reserve's Board of Governors included five appointees and two ex-officio members, the Secretary of Treasury and the Comptroller of the Currency. This governance structure gave the Secretary of the Treasury a disproportionate influence over monetary policy, since the five appointees to the Board were reluctant to cross the Treasury. Faced with a 25 -fold increase in gross public debt after the War (Meltzer 2003), the Secretary refused to support an increase in discount rates despite an acceleration in inflation into double digits in $1919.5 \quad$ However, the Treasury's reputation was

\footnotetext{
4 Unlike the Civil war period, in which the dollar was allowed to float, the official price of gold remained fixed during WWI. Thus, the task facing policymakers was to ensure that gold reserves were sufficient to support free convertibility after the lifting of the embargo.

5 The System's most potent policy instrument was the discount rate charged by the System's Reserve Banks to
} 
strongly linked to the success of the gold standard. In particular, U.S. law required the Treasury to ensure a stock of monetary gold equal to at least 40 percent of the supply of base money. By November 1919, sizeable gold outflows put the legal minimum in sight, and the Treasury finally supported Board action to raise the discount rate.

Once freed to act, the Board raised the System-wide average discount rate over 2 percentage points between late 1919 and mid-1920 (see Figure 3). Although an eventual tightening of policy was anticipated insofar as private agents believed that the government was committed to defending the Gold standard, both the timing and severity of the contraction were a surprise. The highly persistent rise in nominal rates in the face of rapidly shifting expectations about inflation (i.e., towards deflation) represented a much tighter policy stance than agents had anticipated. As seen in Figure 3, the aggregate price level (measured by the GNP deflator) plunged over 20 percent between mid-1920 and mid-1921, and commodity prices declined even more precipitously. Real GDP nosedived over 20 percent from its late 1919 peak, and the FRB index of industrial production fell more than 50 percent. Nevertheless, as observed by Friedman and Schwartz, the relatively short-lived nature of the depression is as striking as its magnitude, with a robust expansion returning output to its pre-deflation level by early 1922 .

In comparing episodes, the post-WWI experience was similar to the 1869-1879 period insofar as the credibility of the authorities'commitment to the Gold standard seems beyond doubt. By the 1920s, the Gold standard was entrenched as both a national and international norm, and even countries that had experienced much larger wartime inflations expected to return to gold. The high credibility of the monetary regime ultimately served an important role in allowing the economy to recover quickly once it was clear that prices had fallen enough. But clearly, the major difference between the episodes was in the Federal Reserve's decision to implement a very rapid deflation in the early 1920s, which contrasted starkly with the gradualist policy of 18691879. Influential Federal Reserve policymakers including Benjamin Strong believed that it was of its member commercial banks on short-term loans. The Reserve Banks could request an adjustment in its discount rate, but the Board had to approve. 
foremost importance to reverse quickly most of the price level increase that had occurred since the U.S. entry into the war; while they acknowledged this might cause a substantial output contraction, they believed the recessionary effects would be transient and did not warrant dragging out the deflation (Meltzer 2003). Thus, policymakers kept nominal interest rates at elevated levels even as prices fell dramatically. This departure from traditional gold standard rules - which would have prescribed cutting interest rates in the face of a massive deflation and sizeable gold inflows - helped create a depression in activity through its effect on real interest rates.

\subsection{Volcker Disinflation (1981-1984)}

As of 1979, the Federal Reserve had been in operational control of U.S. monetary policy for about 25 years, even if it remained sensitive to the political climate. The Accord of 1951 between the central bank and the Treasury had ceded monetary policy to the Federal Reserve. For a dozen years after the Accord, the Federal Reserve generally maintained a low and steady inflation rate. But beginning in the mid-1960s, the Federal Reserve permitted inflation to rise to progressively higher levels. By the time President Carter appointed in 1979 a well-known inflation "hawk", Paul Volcker, to run the Federal Reserve, (GNP) price inflation had reached 9 percent.

Two months after taking office in August 1979, Volcker announced a major shift in policy aimed at rapidly lowering the inflation rate. Volcker desired the policy change to be interpreted as a decisive break from past policies that had allowed the inflation rate to rise to double digit levels (Figure 4). The announcement was followed by a series of sizeable hikes in the federal funds rate: the roughly 7 percentage point rise in the nominal federal funds rate between October 1979 and April 1980 (see Figure 4) represented the largest increase over a sixth month period in the history of the Federal Reserve System. However, this tight monetary stance was temporarily abandoned in mid-1980 as economic activity decelerated sharply. Reluctantly, the FOMC imposed credit controls and let the funds rate decline - moves that the Carter Administration had publically supported. The FOMC's policy reversal and acquiesence to political pressure was widely viewed 
as a signal that it was not committed to achieving a sustained fall in inflation (Blanchard, 1984). Having failed to convince price and wage setters that inflation was going to fall, and GNP prices rose almost 10 percent in 1980 .

The Federal Reserve embarked on a new round of monetary tightening in late 1980 . The federal funds rate rose to 20 percent in late December, implying an ex post real interest rate of about 10 percent. Real ex post rates were allowed to fall only slightly from this extraordinarily high level over the following two years. Newly-elected President Reagan's support of Volcker's policy was significant in giving the Federal Reserve the political mandate it needed to keep interest rates elevated for a prolonged period (Feldstein 1993), and provided some shield from growing opposition in Congress. This second and more durable round of tightening succeeded in reducing the inflation rate from about 10 percent in early 1981 to about 4 percent in 1983 . The cost was a sharp and very prolonged recession, with the CBO measure of the output gap expanding to 9 percent of GDP by mid-1982 (n.b. the plot shows the output gap by rescaling relative to its 1980 level, when the CB0's measure of the gap was already about 3 percent), and the the unemployment rate (not shown) hovered at 10 percent until late 1983.

While policymakers in the Gold standard environment examined in the earlier episodes had the advantage of a transparent and credible long-run nominal anchor, the Volcker disinflation was conducted in a setting in which there was a high degree of uncertainty about long-run inflation: as seen in Figure 4, it took many years for longer term inflation forecasts - such as the Blue Chip survey of inflation expectations 5-10 years ahead - to converge to the low inflation rates that prevailed post-1983. But notwithstanding that Federal Reserve policy during the 1970s and early 1980s merits some criticism for a lack of transparent objectives, it seems unlikely that simple announcements about long-run policy goals (e.g., an inflation target of three percent) would have carried much weight given the poor track record of the preceding two decades. Thus, it seems arguable that Volcker's FOMC had little hope of harnessing inflation expectations in a way that could facilitate lower inflation without sizeable output costs. Inflation had to be reduced through 
the tough medicine of keeping real interest rates persistently high, until markets gradually adjusted their beliefs about the central bank's underlying policy goals, and its ability to achieve them.

\section{Policy Predictability: Evidence from Forecast errors}

Data on expectations after the Civil War are derived from two sources. The first is Calomiris $(1985,1993)$. He shows data suggesting that agents' forecast errors of greenback appreciation (i.e., price deflation) were fairly small. The forecast of greenback appreciation is computed as the difference between greenback-denominated railroad bonds and a gold-denominated U.S. Treasury bond. In Figure 2, we plot Calomiris' data and observe that the forecast errors were quite small, typically less than one percentage point on average.

We investigated the robustness of Calomiris' results to the use of different railroad yields. Our exercise considers two bonds from different major railroads that mature within two years of the U.S. gold bond, and follows them through our sample period of 1869-78. Given the gold-denominated Treasury bond used in Calomiris, we can compute two series of forecast errors. The results are also summarized in Figure 2. The figure shows an average error - across time and railroads - of about -0.5 percentage points. The average error over the same period in the Calomiris data is about -0.2 percentage points. Interestingly, the forecast errors are fairly small even during the latter half of the 1870s, a period of particularly large price declines.

We can reinforce our message regarding the post-Civil War deflation with commodity futures data. We collected data on the longest-to-maturity futures contract that were fairly regularly available, which consisted of either 4 or 5 month contracts on pork, corn, wheat, and lard. The data are plotted in Figure 1 (lower right quadrant). The actual (or realized) prices are taken from the NBER's macro history database when available, and otherwise, from annual reports of the Chicago Board of Trade (the futures prices were reported in The Chicago Tribune). Over the period from 1871 through 1878, forecast errors seem relatively small, especially given the substantial volatility in spot prices of the underlying commodities. The average absolute error 
across commodities and time was around 10 percentage points. Moreover, the errors were not consistently negative, suggesting that agents did not repeatedly underestimate the deflation.

In contrast, in the post-World War I deflation, commodity price forecast errors turned consistently negative shortly after monetary policy was tightened in early 1920, and reached 50 percentage points or higher (Figure 3). The futures data on corn and oats are from the Annual Reports of the Chicago Board of Trade, as in Hamilton (1992). Cotton futures traded on the New York commodity futures exchange, and their data is recorded in the Commercial and Financial Chronicle. Figure 3 shows large negative forecast errors among all three around the same time, namely, from May 1920 through October or November of the same year. Agents do not seem to have anticipated the initial deflation after World War I, although it did not take them too long to learn the future path of policy. The average forecast errors over the 1920-21 tightening period over roughly three times as large as the commodity price forecast errors derived from the post-Civil War data.

Lastly, we can contrast the forecast errors from the post-Civil War episode with the data on observed expectations in the 1981-82 tightening. Figure 4 largely summarizes our case for the Volcker disinflation. We plot professional forecasters' one-year-ahead inflation expectations and the realized level of inflation four quarters later. We also include in the figure data on 10-year average inflation expectations. The one-year-ahead forecasts are the median projections of GNP price inflation from the Survey of Professional Forecasters. The long-run expectations are from the semiannual Blue Chip survey. Both series tell the same story: agents' forecasts were persistently too high. Based on one-year-ahead forecasts, we find that the average forecast error over this period equaled -2 percentage points.

\section{The Model}

We utilize the same basic model to analyze each of the three historical episodes, aside from differences in the characterization of monetary policy. The model can be regarded as a slightly 
simplified version of the model utilized by Christiano, Eichenbaum and Evans (2005), and Smets and Wouters (2003). Thus, our model incorporates nominal rigidities by assuming that labor and product markets each exhibit monopolistic competition, and that wages and prices are determined by staggered nominal contracts of random duration (following Calvo (1983) and Yun (1996)). We also include various real rigidities emphasized in the recent literature, including habit persistence in consumption, and costs of changing the rate of investment. Given that our characterization of monetary policy differs across episodes, we defer this discussion to Section 6 (when we present simulation results for each episode).

\subsection{Firms and Price Setting}

Final Goods Production As in Chari, Kehoe, and McGratten (2000), we assume that there is a single final output good $Y_{t}$ that is produced using a continuum of differentiated intermediate goods $Y_{t}(f)$. The technology for transforming these intermediate goods into the final output good is constant returns to scale, and is of the Dixit-Stiglitz form:

$$
Y_{t}=\left[\int_{0}^{1} Y_{t}(f)^{\frac{1}{1+\theta_{p}}} d f\right]^{1+\theta_{p}}
$$

where $\theta_{p}>0$.

Firms that produce the final output good are perfectly competitive in both product and factor markets. Thus, final goods producers minimize the cost of producing a given quantity of the output index $Y_{t}$, taking as given the price $P_{t}(f)$ of each intermediate good $Y_{t}(f)$. Moreover, final goods producers sell units of the final output good at a price $P_{t}$ that is equal to the marginal cost of production:

$$
P_{t}=\left[\int_{0}^{1} P_{t}(f)^{\frac{-1}{\theta_{p}}} d f\right]^{-\theta_{p}}
$$

It is natural to interpret $P_{t}$ as the aggregate price index.

Intermediate Goods Production $A$ continuum of intermediate goods $Y_{t}(f)$ for $f \in[0,1]$ is produced by monopolistically competitive firms, each of which produces a single differentiated 
good. Each intermediate goods producer faces a demand function for its output good that varies inversely with its output price $P_{t}(f)$, and directly with aggregate demand $Y_{t}$ :

$$
Y_{t}(f)=\left[\frac{P_{t}(f)}{P_{t}}\right]^{\frac{-\left(1+\theta_{p}\right)}{\theta_{p}}} Y_{t}
$$

Each intermediate goods producer utilizes capital services $K_{t}(f)$ and a labor index $L_{t}(f)$ (defined below) to produce its respective output good. The form of the production function is Cobb-Douglas:

$$
Y_{t}(f)=K_{t}(f)^{\alpha} L_{t}(f)^{1-\alpha}
$$

Firms face perfectly competitive factor markets for hiring capital and the labor index. Thus, each firm chooses $K_{t}(f)$ and $L_{t}(f)$, taking as given both the rental price of capital $R_{K t}$ and the aggregate wage index $W_{t}$ (defined below). Firms can costlessly adjust either factor of production. Thus, the standard static first-order conditions for cost minimization imply that all firms have identical marginal cost per unit of output. By implication, aggregate marginal cost $M C_{t}$ can be expressed as a function of the wage index $W_{t}$, the aggregate labor index $L_{t}$, and the aggregate capital stock $K_{t}$, or equivalently, as the ratio of the wage index to the marginal product of labor $M P L_{t}$ :

$$
M C_{t}=\frac{W_{t} L_{t}^{\alpha}}{(1-\alpha) K_{t}^{\alpha}}=\frac{W_{t}}{M P L_{t}}
$$

We assume that the prices of the intermediate goods are determined by Calvo-Yun style staggered nominal contracts. In each period, each firm $\mathrm{f}$ faces a constant probability, $1-\xi_{p}$, of being able to reoptimize its price $P_{t}(f)$. The probability that any firm receives a signal to reset its price is assumed to be independent of the time that it last reset its price. If a firm is not allowed to optimize its price in a given period, we follow Yun (1996) by assuming that it simply adjusts its price by the steady state rate of inflation $\pi$ (i.e., $P_{t}(f)=\pi P_{t-1}(f)$ ). Finally, the firm's output is subsidized at a fixed rate $\tau_{p}$ (this allows us to eliminate the monopolistic competition wedge in prices by setting $\left.\tau_{p}=\theta_{p}\right)$. 


\subsection{Households and Wage Setting}

We assume a continuum of monopolistically competitive households (indexed on the unit interval), each of which supplies a differentiated labor service to the production sector; that is, goodsproducing firms regard each household's labor services $N_{t}(h), h \in[0,1]$, as an imperfect substitute for the labor services of other households. It is convenient to assume that a representative labor aggregator (or "employment agency") combines households' labor hours in the same proportions as firms would choose. Thus, the aggregator's demand for each household's labor is equal to the sum of firms' demands. The labor index $L_{t}$ has the Dixit-Stiglitz form:

$$
L_{t}=\left[\int_{0}^{1} N_{t}(h)^{\frac{1}{1+\theta} w} d h\right]^{1+\theta_{w}}
$$

where $\theta_{w}>0$. The aggregator minimizes the cost of producing a given amount of the aggregate labor index, taking each household's wage rate $W_{t}(h)$ as given, and then sells units of the labor index to the production sector at their unit cost $W_{t}$ :

$$
W_{t}=\left[\int_{0}^{1} W_{t}(h)^{\frac{-1}{\theta} w} d h\right]^{-\theta_{w}}
$$

It is natural to interpret $W_{t}$ as the aggregate wage index. The aggregator's demand for the labor hours of household $h$ - or equivalently, the total demand for this household's labor by all goods-producing firms - is given by

$$
N_{t}(h)=\left[\frac{W_{t}(h)}{W_{t}}\right]^{-\frac{1+\theta_{w}}{\theta_{w}}} L_{t}
$$

The utility functional of a typical member of household $h$ is

$$
\begin{aligned}
& \mathbb{E}_{t} \sum_{j=0}^{\infty} \beta^{j}\left\{\frac{1}{1-\sigma}\left(C_{t+j}(h)-\varkappa C_{t+j-1}(h)\right)^{1-\sigma}+\right. \\
& \left.\frac{\chi_{0}}{1-\chi}\left(1-N_{t+j}(h)\right)^{1-\chi}+\frac{\mu_{0}}{1-\mu}\left(\frac{M_{t+j}(h)}{P_{t+j}}\right)^{1-\mu}\right\}
\end{aligned}
$$

where the discount factor $\beta$ satisfies $0<\beta<1$. The dependence of the period utility function on consumption in both the current and previous period allows for the possibility of external habit 
persistence in consumption spending (e.g., Smet and Wouters, 2003). In addition, the period utility function depends on current leisure $1-N_{t}(h)$, and current real money balances. $\frac{M_{t}(h)}{P_{t}}$.

Household $h$ 's budget constraint in period $t$ states that its expenditure on goods and net purchases of financial assets must equal its disposable income:

$$
\begin{gathered}
P_{t} C_{t}(h)+P_{t} I_{t}(h)+\frac{1}{2} \psi_{I} P_{t} \frac{\left(I_{t}(h)-I_{t-1}(h)\right)^{2}}{I_{t-1}(h)} \\
M_{t+1}(h)-M_{t}(h)+\int_{s} \xi_{t, t+1} B_{D, t+1}(h)-B_{D, t}(h) \\
=\left(1+\tau_{W}\right) W_{t}(h) N_{t}(h)+R_{K t} K_{t}(h)+\Gamma_{t}(h)-T_{t}(h)
\end{gathered}
$$

Thus, the household purchases the final output good (at a price of $P_{t}$ ), which it chooses either to consume $C_{t}(h)$ or invest $I_{t}(h)$ in physical capital. The total cost of investment to each household $h$ is assumed to depend on how rapidly the household changes its rate of investment (as well as on the purchase price). Our specification of such investment adjustment costs as depending on the square of the change in the household's gross investment rate follows Christiano, Eichenbaum, and Evans (2005). Investment in physical capital augments the household's (endof-period) capital stock $K_{t+1}(h)$ according to a linear transition law of the form:

$$
K_{t+1}(h)=(1-\delta) K_{t}(h)+I_{t}(h)
$$

In addition to accumulating physical capital, households may augment their financial assets through increasing their nominal money holdings $\left(M_{t+1}(h)-M_{t}(h)\right)$, and through the net acquisition of bonds. We assume that agents can engage in frictionless trading of a complete set of contingent claims. The term $\int_{s} \xi_{t, t+1} B_{D, t+1}(h)-B_{D, t}(h)$ represents net purchases of statecontingent domestic bonds, with $\xi_{t, t+1}$ denoting the state price, and $B_{D, t+1}(h)$ the quantity of such claims purchased at time $t$. Each member of household $h$ earns labor income $\left(1+\tau_{W}\right) W_{t}(h) N_{t}(h)$ (where $\tau_{W}$ is a subsidy that allows us to offset monopolistic distortions in wage-setting), and receives gross rental income of $R_{K t} K_{t}(h)$ from renting its capital stock to firms. Each member 
also receives an aliquot share $\Gamma_{t}(h)$ of the profits of all firms, and pays a lump-sum tax of $T_{t}(h)$ (this may be regarded as taxes net of any transfers).

In every period $t$, each member of household $h$ maximizes the utility functional (9) with respect to its consumption, investment, (end-of-period) capital stock, money balances, and holdings of contingent claims, subject to its labor demand function (8), budget constraint (11), and transition equation for capital (12). Households also set nominal wages in Calvo-style staggered contracts that are generally similar to the price contracts described above. Thus, the probability that a household receives a signal to reoptimize its wage contract in a given period is denoted by $1-\xi_{w}$, and as in the case of price contracts this probability is independent of the date at which the household last reset its wage. However, we specify a dynamic indexation scheme for the adjustment of the wages of those households that do not get a signal to reoptimize, i.e., $W_{t}(h)=$ $\omega_{t} W_{t-1}(h)$,in contrast to the static indexing assumed for prices. As discussed by Christiano, Eichenbaum, and Evans (2005), dynamic indexation of this form introduces some element of structural persistence into the wage-setting process. Our asymmetric treatment is motivated by the empirical analysis of Levin, Onatski, Williams, and Williams (2005). These authors estimated a similar model using U.S. data over the 1955:1-2001:4 period, and found evidence in favor of nearly full indexation of wages, but not of prices (hence our specification of prices as purely forward-looking).

\subsection{Fiscal Policy and the Aggregate Resource Constraint}

The government's budget is balanced every period, so that total lump-sum taxes plus seignorage revenue are equal to output and labor subsidies plus the cost of government purchases:

$$
M_{t}-M_{t-1}+\int_{0}^{1} T_{t}(h) d h=\int_{0}^{1} \tau_{p} P_{t}(f) Y_{t}(f) d f+\int_{0}^{1} \tau_{w} W_{t}(h) N_{t}(h) d h+P_{t} G_{t}
$$

where $G_{t}$ indicates real government purchases. We assume that government spending is a fixed share of output in our analysis. Finally, the total output of the service sector is subject to the 
following resource constraint:

$$
Y_{t}=C_{t}+I_{t}+G_{t}
$$

\section{Solution and Calibration}

To analyze the behavior of the model, we log-linearize the model's equations around the nonstochastic steady state. Nominal variables, such as the contract price and wage, are rendered stationary by suitable transformations. We then compute the reduced-form solution of the model for a given set of parameters using the numerical algorithm of Anderson and Moore (1985), which provides an efficient implementation of the solution method proposed by Blanchard and Kahn (1980).

\subsection{Parameters of Private Sector Behavioral Equations}

The model is calibrated at a quarterly frequency. Thus, we assume that the discount factor $\beta=.995$, consistent with a steady-state annualized real interest rate $\bar{r}$ of about 2 percent. We assume that the subutility function over consumption is logarithmic, so that $\sigma=1$, while we set the parameter determining the degree of habit persistence in consumption $\varkappa=0.6$ (similar to the empirical estimate of Smets and Wouters 2003). The parameter $\chi$, which determines the curvature of the subutility function over leisure, is set equal to 10, implying a Frisch elasticity of labor supply of $1 / 5$. This is considerably lower than if preferences were logarithmic in leisure, but within the range of most estimates from the empirical labor supply literature. The scaling parameter $\chi_{0}$ is set so that employment comprises one-third of the household's time endowment, while the parameter $\mu_{0}$ on the subutility function for real balances is set an arbitrarily low value (so that variation in real balances has a negligible impact on other variables). The share of government spending of total expenditure is set equal to 12 percent, while the autoregressive parameter of the government spending shock is set close to unity (i.e., $\varphi_{G}=0.999$ - this is simply to capture that the decline in wartime spending following the WWI armistice was viewed as highly persistent).

The capital share parameters $\alpha=1 / 3$. The quarterly depreciation rate of the capital stock $\delta=$ 
0.02, implying an annual depreciation rate of 8 percent. The price and wage markup parameters $\theta_{P}=\theta_{W}=1 / 5$. We set the cost of adjusting investment parameter $\phi_{I}=1$, which is somewhat smaller than the value estimated by Christiano, Eichenbaum, and Evans (2001) using a limited information approach; however, the analysis of Erceg, Guerrieri, and Gust (2005) suggests that a lower value in the range of unity may be better able to capture the unconditional volatility of investment within a similar modeling framework. We assume that price contracts last three quarters, while nominal wage contracts last four quarters. The calibration of contract duration is in the range typically estimated in the literature.

\section{Model Simulations}

\subsection{The Post Civil War Deflation}

While we will attempt to use our model to account for the evolution of real activity during the latter two episodes - on the premise that monetary changes played a principal role in driving the real fluctuations that occurred - our objective in applying the model to the post Civil War deflation is narrower in scope. In particular, while a more complicated model with a richer set of shocks would be required to account for output behavior over the long period prior to Resumption, our focus here is simply to rationalize why the "secular" deflation of 2-3 percent per year appeared to exert little drag on output growth in the decade following the Public Credit Act of 1869.

In this vein, we characterize the monetary authorities in the 1869-1879 period as following a simple targeting rule derived from minimizing a loss function that depends on the gap between the price level $p_{t}$ and its target value $p_{t}^{*}$ (which we call the price level gap), and on the output gap $g_{t}$. Under a quadratic period loss function in each of these gaps, the targeting rule is derived by minimizing a discounted conditional loss function of the form:

$$
\mathbb{E}_{t} \sum_{j=0}^{\infty} \beta^{j}\left\{\left(p_{t+j}-p_{t+j}^{*}\right)^{2}+\lambda_{G} g_{t+j}^{2}\right\}
$$

subject to the behavioral constraints implied by household and firm optimization from the model 
of Section $4 .^{6}$

The solid blue line in Figure 5 presents our benchmark characterization of the post Civil War deflation period in response to a permanent reduction in $p_{t}^{*}$ of 30 percent. The weight on the output gap in the loss function is chosen to stretch out the price decline over the course of a decade, so that the simulated price level decline appears quite similar to the historical experience (this is achieved by setting $\lambda_{G}=10^{\wedge} 4$ in (15)). It is evident from the figure that the large cumulative decline in prices has little impact on real activity: in fact, output never falls more than 0.1 percent below potential. The optimal policy achieves this sizeable price decline at minimal output cost by relying heavily on an "expectations channel": current price-setters are willing to lower prices today in the expectation that future prices will be lower (and hence deflation does not require a recession). A notable characteristic of the optimal policy is that it implies a persistent decline in short-term nominal interest rates, which is consistent with the policy shift exerting little effect on long-term real interest rates.

We believe that this simple characterization of policy captures many of the relevant features of the historical environment following the passage of the Public Credit Act in 1869 that were recounted in Section 2. These features included the mandate to effect a substantial reduction in the general price level, subject to the proviso that the deflation would be gradual enough to avoid a reprise of the post war monetary recession, and the ability of the authorities to commit to such a policy. Admittedly, our characterization abstracts from some aspects of implementation that were discussed in Section 2, including the operational procedure of controlling the monetary base. However, taking account of such features would require significant complications to our model, and would seem highly unlikely to change our basic message that a very gradual and predictable deflation exerts small effects on real activity under a reasonable and well-understood rule (specified either in terms of the money stock or nominal interest rate). ${ }^{7}$

\footnotetext{
6 See Svensson (2003) and Woodford (2003) for extensive discussions of the use of targeting rules to characterize monetary policy.

7 It is worth noting that the optimal targeting rule implies a complicated underlying interest rate reaction
} 
But given the neglible output losses under the ten year implementation window, it is also natural to inquire whether the 1869-1879 price level decline could have occurred more rapidly without significantly exacerbating the effects on the real economy: did the authorities perhaps become overly cautious in response to the public acrimony that followed their first attempts to deflate? This rather general question about how quickly a deflation can be implemented without causing substantial fallout on the real economy has close parallel in earlier work by Taylor (1983) and Ball (1994), but with the important difference that the latter authors assessed how the real costs depended on the horizon over which the inflation rate was changed, rather than the price level. While these authors found that a disinflation could be implemented over a short horizon of roughly two years or less with minimal output costs, our results suggest that a considerably longer horizon is required to implement a change in the price level; the difference reflects that while the staggered contracts framework implies little endogenous persistence in the inflation rate - so that it is relatively easy for inflation to jump - it implies considerably more price level persistence. Under our baseline calibration, the implied tradeoff between a shorter horizon for implementing the disinflation and higher output losses can be derived by varying the relative weight on the output gap $\left(\lambda_{G}\right)$ in the targeting rule (15). Two alternative cases are shown in Figure 5 . The dashed green line shows that a value of $\lambda_{G}$ which causes the 30 percent price decline to occur over only four years causes the output loss to rise to about 1 percent, which still seems quite modest. However, while our benchmark model allows an inflation target to be reduced over a narrow 2 year window with minimal output losses (as verified below, consistent with the earlier literature cited), implementing a new price level target over such an abbreviated time frame causes a pronounced recession (as depicted by the red dash-dotted line).

These results suggest that the ten year window for phasing in the deflation might have been reduced considerably without much of an adverse effect on output. Moreover, to the extent

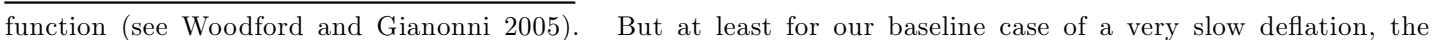
targeting rule can be approximated fairly well by a simple instrument rule in which the ex post real interest rate responds to the price level gap and output gap. 
that wages and prices may have been somewhat more flexible in this episode than implied by our benchmark calibration, the output losses associated with shortening the implementation horizon would be mitigated relative to those indicated in Figure 5. Nevertheless, provided there is some sluggishness in prices and wages - even if less than embedded in our benchmark - real interest rates must rise sharply to implement a discrete downward shift in the price level over a short horizon. Thus, it is arguable that a short implementation window in the neighborhood of a year or two might have risked a substantial recession.

\subsection{The Post World War I Deflation}

We now turn to using our model to characterize the severe monetary recession that began in 1920. As discussed above, the salient feature was a precipitous and largely unexpected decline in the price level of roughly 25 percent over a period of less than two years, and sharp but short-lived contraction in activity. Our model simulations in Figure 5 suggest that attempting to achieve a new price level objective so quickly would precipitate a severe recession even under a well-designed policy derived in an optimization-based setting. But given that monetary policy seemed far from optimal during the 1920s, it remains of interest to assess the implications of a large shift in the price level target under an alternative monetary rule that may better account for the nature of policy.

Despite obvious difficulties in characterizing policy during this turbulent period, we believe that many of the prominent features of the policymaking framework can be summarized in a simple instrument rule of the form:

$$
i_{t}=\gamma_{i} i_{t-1}+\gamma_{P}\left(p_{t}-p_{t}^{*}\right)
$$

This rule posits the nominal interest rate $i_{t}$ as responding to the price level gap $\left(p_{t}-p_{t}^{*}\right)$, as well as to its own lag (a constant term is suppressed for simplicity). This specification has two salient features. First, policy rates are driven exclusively by the difference between the current price 
level and its target $p_{t}^{*}$. This specification is intended to capture the belief of key Federal Reserve policymakers that continued adherence to the Gold standard hinged on rolling back the rise in the U.S. price level that had occurred following the U.S. entry into the war. While it was recognized that real activity might suffer in the short-run, it was regarded of paramount importance to reduce prices enough to faciliate an adequate buildup of gold reserves. The second key feature of (16) is that nominal rates do not respond to inflation (either ex post or ex ante). As shown below, this helps account for the empirical observation that nominal rates remained high despite an enormous decline in the price level in 1920-21. This feature of the instrument rule evidently contrasts with the behavior of nominal rates under the optimal rule shown in Figure 5, in which declining inflation exerts sizeable downward pressure on nominal rates.

We attempt to account for this historical episode through a model simulation in which the price level target $p_{t}^{*}$ is reduced by 25 percent beginning in 1920:1. Private agents are assumed to observe the underlying price level target, which we interpret as consistent with the high credibility of the authorities' policy to support the Gold standard through monetary tightening. The price level target is assumed to follow an exogenous random walk, so that any shift in the target is perceived as permanent. We assume that the shock is phased-in equally over three quarters, in part to match the modest persistence suggested by the commodity price forecast errors discussed in Section 3 (however, this phasing-in has been minor consequences for our results). Finally, we set $\gamma_{i}=.5$ to allow for a bit of interest rate smoothing, and $\gamma_{P}=.04$ in order to allow our model to do reasonably well in matching the rise in nominal interest rates that occurred in the historical episode.

Simulation results for our benchmark case are shown by the solid blue lines in Figure 6 . The model evidently accounts quite well for the observed sharp fall in the price level beginning in mid1920. From a specification standpoint, the dramatic price decline would be difficult to rationalize in a model that incorporated significant structural persistence into the price-setting process; in our framework, relatively short-lived (three quarter) non-indexed Calvo contracts provide a better 
account of the rapid price decline than would price contracts allowing for dynamic indexation. The model also does quite well in accounting for the large output decline observed, and for the rapid recovery in 1921. The output decline in our model simulation is attributable to a sizeable and fairly persistent rise in the real interest rate. The substantial rise in real long-term interest rates despite little movement in the nominal interest rate reflects both that agents came to expect large price declines, and that policy would maintain high nominal rates even in a deflationary environment.

Thus, our simulation results suggest that the high costs of the 1920-21 deflation reflect that the Federal Reserve attempted to engineer an extremely rapid deflation, and that it was perceived as following a monetary policy stance in which future nominal rates were expected to remain high (at least for a few quarters) in the face of deflation: in effect, consistent with our historical analysis, the Federal Reserve used the blunt instrument of a severe recession to push down prices, rather than operating through an expectations channel. Accordingly, it is of interest to consider the counterfactual simulation depicted by the dotted green lines, which shows a case in which the central bank is assumed to change its target path level incrementally, and to follow a rule in which the nominal interest rate also responds to ex post inflation (but is otherwise identical to equation (16)). Clearly, while allowing for nominal rates to decline with inflation would have induced a more gradual convergence in prices to target, it would have greatly ameliorated the output costs. Obviously, even more favorable outcomes could be derived to the extent that policy could better approximate the optimal targeting rules discussed in the previous section rather than a simple ad hoc instrument rule.

\subsection{The Volcker Disinflation}

A striking feature of the Volcker disinflation period was the fact that inflation forecast errors were extremely persistent. Erceg and Levin (2003) argued that the persistence in the forecast errors - and associated high persistence in realized inflation - may have reflected a high level of 
uncertainty about the central bank's inflation target. ${ }^{8}$ In this paper, we take a similar stylized approach to characterizing uncertainty about the inflation target of the central bank by assuming that agents cannot differentiate permanent shocks to the inflation target from transient shocks to the monetary policy reaction function.

In particular, agents perceive the central bank's reaction function to have the same basic form as equation (15)except that it also includes a random policy shock $e_{q t}$ :

$$
i_{t}=\gamma_{i} i_{t-1}+\left(1-\gamma_{i}\right)\left(\bar{r}+\pi_{t}\right)+\gamma_{\pi}\left(\pi_{t}-\pi_{t}^{*}\right)+\gamma_{y} \ln \left(y_{t} / y_{t-4}\right)+e_{q t}
$$

We assume that agents cannot directly observe the long-run inflation target $\pi_{t}^{*}$, or the monetary shock $e_{q t}$; but given that agents observe interest rates, inflation, and output growth (as well as all of the structural parameters of the model), they can infer a composite shock $\phi_{t}$ which is a hybrid of the inflation target and the random policy innovation:

$$
\phi_{t}=-\gamma_{G} \pi_{t}^{*}+e_{q t}
$$

The unobserved components in turn are perceived to follow a first-order vector autoregression:

$$
\left[\begin{array}{c}
\pi_{t}^{*} \\
e_{q t}
\end{array}\right]=\left[\begin{array}{cc}
\rho_{p} & 0 \\
0 & \rho_{q}
\end{array}\right]\left[\begin{array}{l}
\pi_{t-1}^{*} \\
e_{q t-1}
\end{array}\right]+\left[\begin{array}{cc}
v_{1} & 0 \\
0 & v_{2}
\end{array}\right]\left[\begin{array}{c}
\varepsilon_{p t} \\
\varepsilon_{q t}
\end{array}\right]
$$

The inflation target $\pi_{t}^{*}$ is highly persistent, and has an autoregressive root $\rho_{p}$ arbitrarily close to unity. For simplicity, we assume that the random policy shock $e_{q t}$ is white noise (so $\rho_{q}=0$ ). The innovations associated with each shock, $\varepsilon_{p t}$ and $\varepsilon_{q t}$, are mutually uncorrelated with unit variance.

Given this linear structure, we assume that agents use the Kalman filter to make optimal projections about the unobserved inflation target $\pi_{t}^{*}$. The inflation target perceived by agents evolves according to a first order autoregression. Agents update their their assessment of the

\footnotetext{
8 These authors argued that inflation persistence was not structural, but due to uncertainty about the conduct of monetary policy. Cogley and Sargent (2001) present econometric evidence that inflation persistence is regimedependent using a time-varying coefficients model.
} 
inflation target by the product of the forecast error innovation and a constant coefficient. This coefficient, which is proportional to the Kalman gain, is expressed as a function of the signalto-noise ratio $\left(\gamma_{\pi} \frac{v_{1}}{v_{2}}\right)$. Clearly, the signal-to-noise ratio depends on the relative magnitude of innovations to each of the components of the observed shock $\phi_{t}$; but importantly, it also depends directly on the weight $\gamma_{\pi}$ on the inflation target in the central bank's reaction function. Intuitively, if policy is aggressive in reacting to the inflation gap, agents will attribute more of any unexplained rise in interest rates (i.e., relative to a rule with a constant inflation target) to a reduction in the central bank's long-run inflation target.

As argued by Erceg and Levin (2003) in the context of a somewhat simpler dynamic model, the signal-to-noise ratio plays a crucial role in affecting model responses to a shock to the inflation target. Following their approach, we estimate this composite parameter (i.e., $\frac{v_{1}}{v_{2}}$, using the estimated value of $\gamma_{\pi}$ ) by choosing the value that minimizes the difference between historical four quarter-ahead expected inflation (taken from survey data) and the corresponding expected inflation path implied by our model. In particular, we minimize the loss function:

$$
\text { Loss }=\sum_{j=0}^{20}\left[\mathbb { E } _ { t + j } \left(\pi_{t+3+j}^{4}(\text { survey data })-\mathbb{E}_{t+j}\left(\pi_{t+3+j}^{4}(\bmod e l)\right]^{2}\right.\right.
$$

The estimation period is 1980:4-1985:4 (21 quarters). The model expectation in (20) is the expected rate of four-quarter inflation that agents project at each date, given an assumed onetime shift in the inflation target of six percentage points that occurs in 1980:4. Our estimation routine yields a point estimate of $\left(\frac{v_{2}}{v_{1}}\right)$ that implies a coefficient on the forecast error innovation in equation (??) of about 0.09 . This value is broadly similar to the 0.13 derived in the earlier Erceg-Levin analysis that utilized four quarter Taylor contracts.

Figure 7 shows the effects of a six percentage point immediate reduction in the Federal Reserve's inflation target in our benchmark model. The learning problem about the inflation target plays a critical role in allowing our model to account the main features of the Volker disinflation episode discussed above, including sluggish inflation adjustment, a persistently negative output gap, and 
an initial rise in the nominal interest rate. Inflation declines in roughly exponential fashion, with about 50 percent of the eventual 6 percentage point fall occurring after four quarters, and virtually all of it after ten quarters. Our model's predicted path for inflation is very similar to that observed during the actual episode. Moreover, long-run expected inflation in our model (see the lower right panel) declines much more slowly than current inflation, which is also consistent with the historical experience. This pattern in our simulation reflects that long-run inflation is largely determined by expectations about the future course of the inflation target, which evolve very slowly, while short-run inflation can drop more quickly in response to the depressed state of real activity.

Our model does remarkably well in accounting for both the magnitude of the output decline and its timing. As seen in the upper left panel, the maximum GDP contraction of around 5$1 / 2$ percent is very similar to the decline in the OECD's measure of the output gap shown in Figure 4; in both cases, the peak decline occurs about six quarters after the initial shock. Our model's ability to capture the timing of the Volcker recession provides support for specifying adjustment costs as dependent on the change in investment, rather than following a traditional Qtheory approach in which adjustment costs depend on the change in capital stock ${ }^{9}$ By contrast, Erceg and Levin (2003) utilized a Q-theory specification, and found that investment dropped precipitously following the initial rise in interest rates, so that the peak decline in both output and the expenditure components occurred roughly one quarter after the shock.

We also find that the ability of our model to account for the Volcker period is enhanced by allowing for the dynamic indexation of wage contracts. In the absence of dynamic wage indexation, real long-term interest rates exhibit a smaller and less persistent increase, and hence our model cannot account for nearly as large an output decline as occurred during the Volcker disinflation. On the other hand, once dynamic wage indexation is included, the fit of the model tends to deteriorate

\footnotetext{
9 Christiano, Eichenbaum, and Evans (2005) argued that such a specification provides a much better account of investment dynamics in response to a monetary policy shock.
} 
on certain key dimensions if dynamic price indexation is also included. In particular, while our benchmark model does quite well in accounting for the more rapid decline in current inflation than expected inflation that characterized the latter stages of the Volcker episode (comparing Figure 8 and 4), this pattern is not captured as well when allowing for dynamic price indexation. With this form of structural persistence in the inflation rate, our model simulations imply that current inflation falls too slowly, and takes too long to converge to its long-term level.

Our model can be applied to evaluate some of the criticism levelled at Volcker's policies. Volcker was subject to vociferous criticism for the rapid pace of the disinflation, and the highly aggressive policy stance required to support it. One might infer from our analysis of Federal Reserve policy in the 1920s that there are strong grounds for criticizing the Volcker disinflation along the same lines, and that some of the high output and employment costs might have been avoided with a more gradualist course.

This critique would seem fairly persuasive if Volcker were acting in a policy environment in which Federal Reserve policies were regarded as highly credible, and if social welfare put a large enough weight on output gap variability relative to deviations in inflation from its long-run target. If policies were highly credible and transparent, allowing for a more gradual convergence of inflation to target might have greatly reduced the output costs, without excessively prolonging the duration of the disinflation. To illustrate this, Figure 8 begins by reconsidering the same-sized shock to the inflation target of six percentage points using our benchmark calibration (including the estimated policy rule), except that we allow agents to perfectly observe the shock to the inflation target $\pi_{t}^{*}$. As might be expected, the cost of the episode is reduced under this alternative information structure, which we interpret as approximating the case of a highly credible and transparent policy environment. In particular, inflation converges to target much more rapidly - in about a year - while the decline in output is much less persistent than under our benchmark calibration with imperfect information. Nevertheless, a policymaker placing a high enough weight on the output gap relative to inflation might view such an outcome as unnecessarily costly. Accordingly, 
the figure also depicts some other feasible choices that would be open to the policymaker in such a complete information environment. These alternatives are derived through placing a smaller weight on inflation - and correspondingly, higher weight on output growth - than in our benchmark calibration, though similar results could be obtained through the familiar analytical device of minimizing a quadratic loss function that depends on the variability of inflation and the output gap (as in Woodford 2003). Clearly, with a low enough relative weight on the inflation gap, the fall in output induced by the inflation target shock would be minimal, while inflation would still converge virtually to baseline in within 3 years, as seen by the red dash-dotted line; and even allowing inflation to fall a bit more slowly than under the benchmark rule would noticeably reduce the output costs, as seen by the green dashed line. Thus, it seems reasonable to argue that a more gradualist course would have been preferable for a policymaker mainly concerned with the output costs of disinflation (captured in spirit through the widespread use of measures such as the sacrifice ratio), provided that the policymaker operated in an environment reasonably close to the complete information world considered in the figure.

However, this argument in favor of a gradualist policy seems less persuasive in an environment similar to that faced by Volcker. Our benchmark model with imperfect information appears suited to examining some of the benefits that might be derived from an aggressive policy stance that accrue through a signalling channel. As seen in equation (??), a given-sized change in the inflation target induces a sharper rise in interest rates if $\gamma_{\pi}$ is large: thus, in an environment where agents must infer policy actions rather than observe them directly, an aggressive policy stance can help them disentangle policy shifts from "discretionary" departures from the perceived policy rule.

In this vein, Figure 9 compares the implications of our benchmark policy rule to two alternative rules that place a smaller weight on the inflation gap. We model the signalling value associated with an aggressive policy response by assuming that the innovations $\nu_{1}$ and $\nu_{2}$ of the observable $\phi_{t}$ are constant in our experiments, which has the effect of reducing the Kalman gain coefficient in equation (??) as $\gamma_{\pi}$ falls. Thus, the Kalman gain coefficient falls from 0.09 in our benchmark 
to 0.05 in the alternative with a coefficient of $\gamma_{\pi}=0.40$ on the inflation target in the monetary rule, and to only 0.03 when the inflation target coefficient declines to $\gamma_{\pi}=0.20$.

Considering the same six percentage point shock to the inflation target, it is evident in the lower right panel that long-term expected inflation declines much more gradually for lower values of $\gamma_{\pi}$. Thus, while long-run expected inflation eventually falls to around 4 percent in our benchmark simulation by the end of the 1980s, it remains entrenched at 6 percent in the alternative with the lowest signal-to-noise ratio (the red dashed-dotted line). Unsurprisingly, output exhibits a smaller short-run contraction under the alternative policy rules relative to our benchmark, reflecting less pronounced increases in short-term real interest rates. This accounts for the smaller rises in real long-term rates shown in the figure. But importantly, because private agents learn more slowly about the new inflation target under the alternatives, output shows a less rapid recovery in these cases than under the benchmark; the divergence in the medium term response of employment (not shown) is even larger (since the recovery in output under the benchmark is muted by the relatively sharp fall in the capital stock).

Thus, while the less aggressive rules succeed in reducing the severity of the initial output downturn relative to our benchmark "Volcker disinflation" calibration, they also lead to a somewhat more protracted recession, and markedly prolong the period over which inflation remains above target. Thus, even if gradualism might seem highly attractive under policy credibility for a wide range of policymaker preferences (provided preferences aren't tilted toward reducing inflation at all cost), a much more aggressive response might be warranted in cases of low policy credibility.

\section{Conclusions}

In this paper, we have examined three famous episodes of deflation (or disinflation) in U.S. history, including episodes following the Civil War, World War I, and the Volcker disinflation of the early 1980s. Our model simulations suggest that the relatively robust output growth that 
occurred during the post-Civil war deflation of the 1870s was facilitated by the highly predictable nature of the price decline. By analogy, a more predictable policy of gradual deflation could have helped avoid the sharp post-WWI downturn. However, our analysis of the Volcker period emphasizes that the strong argument for gradualism that is apparent under a transparent and credible monetary regime becomes less persuasive if the monetary regime lacks credibility: in the latter case, gradualism may simply serve to prolong the suffering associated with a disinflationary episode. Thus, securing the benefits of gradualism requires a supporting institutional framework and communication strategy that allows the private sector to make reliable inferences about the course of policy. 


\section{References}

Anderson, G.S., Moore, G., 1985, A linear algebraic procedure for solving linear perfect foresight models, Economic Letters 17, 247-252.

Balke, Nathan S. and Robert J. Gordon, 1986, Data Appendix B in Robert J. Gordon (ed.) The American Business Cycle: Continuity and Change, Chicago: University of Chicago Press.

Ball, Lawrence, 1995, Disinflation and Imperfect Credibility, Journal of Monetary Economics, 35, 5-24.

Blanchard, Olivier, 1984, The Lucas Critique and the Volcker Disinflation, NBER Working paper 1326.

Blanchard, Olivier and Charles Kahn, 1980, The Solution of Linear Difference Models under Rational Expectations, Econometrica 48, 1305-1311.

Calomiris, Charles, 1985, "Understanding Greenback Inflation and Deflation: An Asset-Pricing Approach," Ph.D. dissertation.

Calomiris, Charles, 1993, "Greenback Resumption and Silver Risk: The Economics and Politics of Monetary Regime Change in the United States, 1862-1900," in Michael D. Bordo and Forrest Capie (eds.), Monetary Regimes in Transition, .Cambridge: Cambridge University Press.

Calvo, Guillermo, 1983, Staggered Prices in a Utility Maximizing Framework, Journal of Monetary Economics, 12, 383-98.

Christiano, Lawrence, Eichenbaum, Martin, and Charles Evans, 1999, Monetary Policy Shocks: What Have We Learned, and to What End? In: Taylor, John and Michael Woodford (Eds.), Handbook of Macroeconomics, Vol 1A, 65-148. 
Christiano, Lawrence, Eichenbaum, Martin, and Charles Evans, 2001, Nominal Rigidities and the Dynamic Effects of Shocks to Monetary Policy, National Bureau of Economic Research Working Paper no. 8403 .

Cogley, Timothy and Thomas Sargent, 2001, "Evolving Post WWII Inflation Dynamics," In Bernanke, Benjamin and Kenneth Rogoff (Eds), Macroeconomics Annual.

Erceg, Christopher, Dale Henderson, and Andrew Levin, 2000, Optimal Monetary Policy with Staggered Wage and Price Contracts, Journal of Monetary Economics, 46, 281-313.

Commercial and Financial Chronicle, 1919-1922, various issues.

Erceg, Christopher, Luca Guerrieri, and Christopher Gust, 2005, Can Long Run Restrictions Identify Technology Shocks? Journal of the European Economic Association, forthcoming.

Erceg, Christopher, and Andrew Levin, 2003, Imperfect Credibility and Inflation Persistence, Journal of Monetary Economics 50, 915-944.

Fisher, Irving, 1920, Stabilizing the Dollar, New York: The MacMillan Company.

Firestone, John, 1960, Federal Receipts and Expenditures during Business Cycles, 1879-1958, Princeton: Princeton University Press.

Friedman, Milton, and Anna Schwartz, 1963, A Monetary History of the United States, 1867-1960, Princeton: Princeton University Press.

Fuhrer, Jeffrey, 2000, Habit Formation in Consumption and Its Implications for Monetary-Policy Models, American Economic Review, 90, 367-90.

Giannoni, Mark and Michael Woodford, 2005, Optimal Inflation Targeting Rules, in: Bernanke, Ben. and Woodford, Michael (eds)., Inflation Targeting, Chicago: University of Chicago Press.

Goodfriend, Marvin, 1997, Monetary Policy Comes of Age: A 20th Century Odyssey, Federal Reserve Bank of Richmond Economic Quarterly 83, 1-24. 
Goodfriend, Marvin and Robert King, 1997, The New Neoclassical Synthesis and the Role of Monetary Policy, in: Bernanke, B.S., Rotemberg, J.J. (eds.), NBER Macroeconomics Annual 1997 (MIT Press: Cambridge), 231-283.

Gordon, Robert, 1982, Why Stopping Inflation May Be Costly: Evidence from Fourteen Historical Episodes, in: Hall, Robert E. (ed.), Inflation: Causes and Effects, Chicago: University of Chicago Press,11-40.

Humphrey, Thomas, 2004, "Classical Deflation Theory," Federal Bank of Richmond Economic Quarterly, 90, 11-32.

Kettl, Donald, 1986, Leadership at the Fed, New Haven: Yale University Press.

Meltzer, Allan, 2003, A History of the Federal Reserve, Volume 1, 1913-1951, Chicago: University of Chicago Press.

Miller, Adolph, 1921, Federal Reserve Policy, American Economic Review, 11, no. 2, 177-206.

Mitchell, Wesley, 1903, A History of the Greenbacks, with Special Reference to the Economic Consequences of their Issue: 1862-1865, Chicago: University of Chicago Press.

Miron, Jeffrey and Christina Romer, 1990, A New Monthly Index of Industrial Production, 18841940, The Journal of Economic History, vol. 50, issue 2, 321-337.

Rockoff, Hugh, 2005, Monetary Statistics before the National Banking Era, in Historical Statistics of the United States, Millenial Editional, Colonial Times to the Present, Cambridge,: Cambridge University Press.

Roll, Richard, 1972, Interest Rates and Price Expectations during the Civil War, The Journal of Economic History, vol 32, issue 2, 476-498

Romer, Christina, 1989, The Prewar Business Cycle Reconsidered: New Estimates of Gross National Product, 1869-1908, Journal of Political Economy, vol. 97, no. 1, 1-37. 
Rotemberg, Julio and Michael Woodford, An Optimization-Based Econometric Framework for the Evaluation of Monetary Policy. in: Bernanke, Ben and Julio Rotemberg (eds.), NBER Macroeconomics Annual 1997, . Cambridge: MIT Press, 297-346.

Sargent, Thomas, 1982, The Ends of Four Big Inflations, in: Hall, Robert (ed.), Inflation: Causes and Effects (University of Chicago Press: Chicago), 41-97.

Sargent, Thomas, 1999,. The Conquest of American Inflation, Princeton: Princeton University Press.

Svensson, Lars, 2003. "What is Wrong with Taylor Rules: Using Judgement in Monetary Policy through Targeting Rules" Journal of Economic Literature, vol. 41, 426-477.

Smets, F. and R. Wouters, 2003. An Estimated Dynamic Stochastic General Equilibrium Model of the Euro Area, Journal of the European Economic Association, vol. 1, 1124-1175.

Taylor, John, 1980, Aggregate Dynamics and Staggered Contracts, Journal of Political Economy, $88,1-24$.

Taylor, John, 1983, Union Wage Settlements during a Disinflation," The American Economic Review, 73, no. 5, 981-994.

Timberlake, Richard H, 1975, The Resumption Act and the Money Supply, Journal of Economic History, 43, no. 3, 729-739.

Woodford, Michael, 2003, Interest and Prices, Princeton: Princeton University Press. 


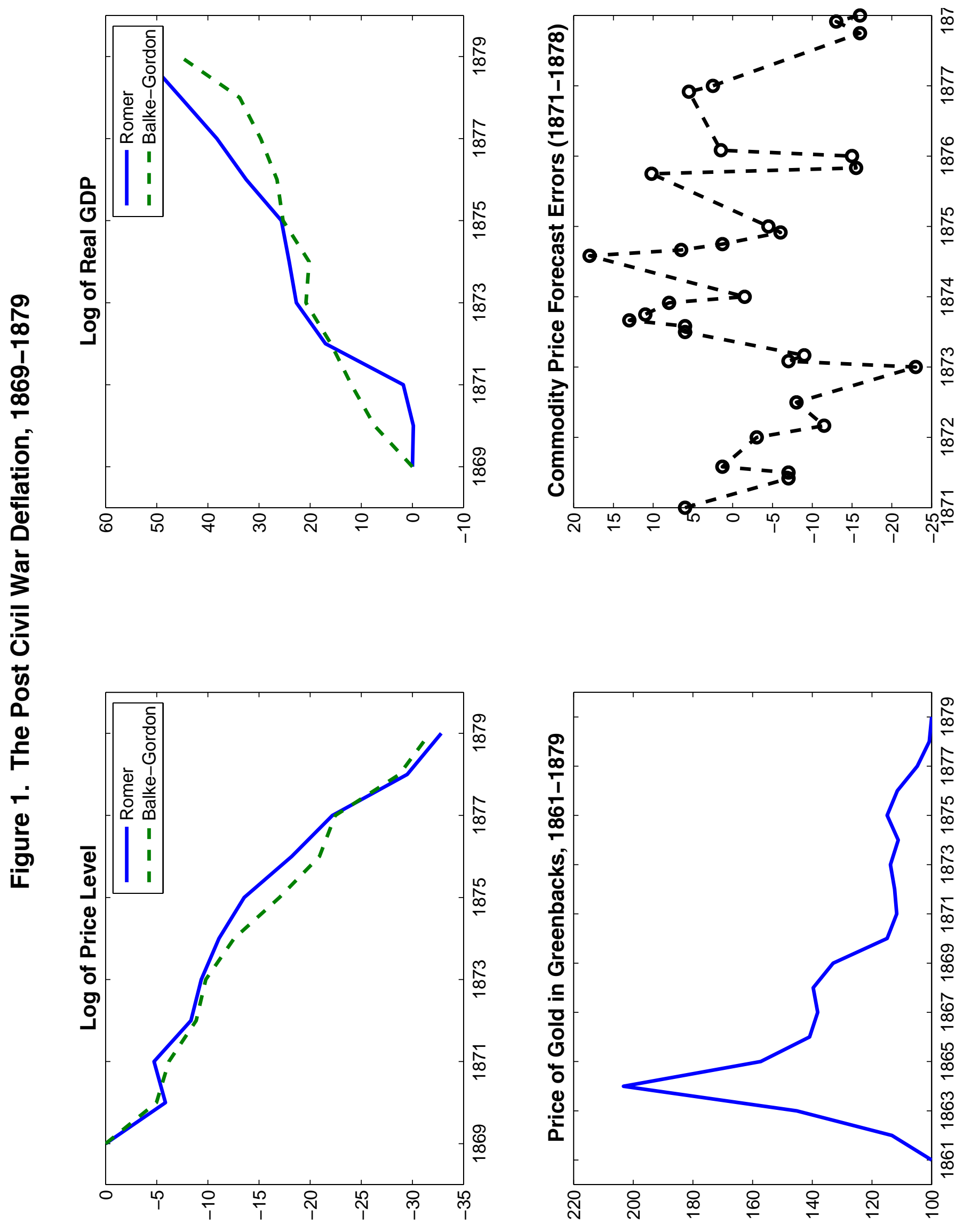




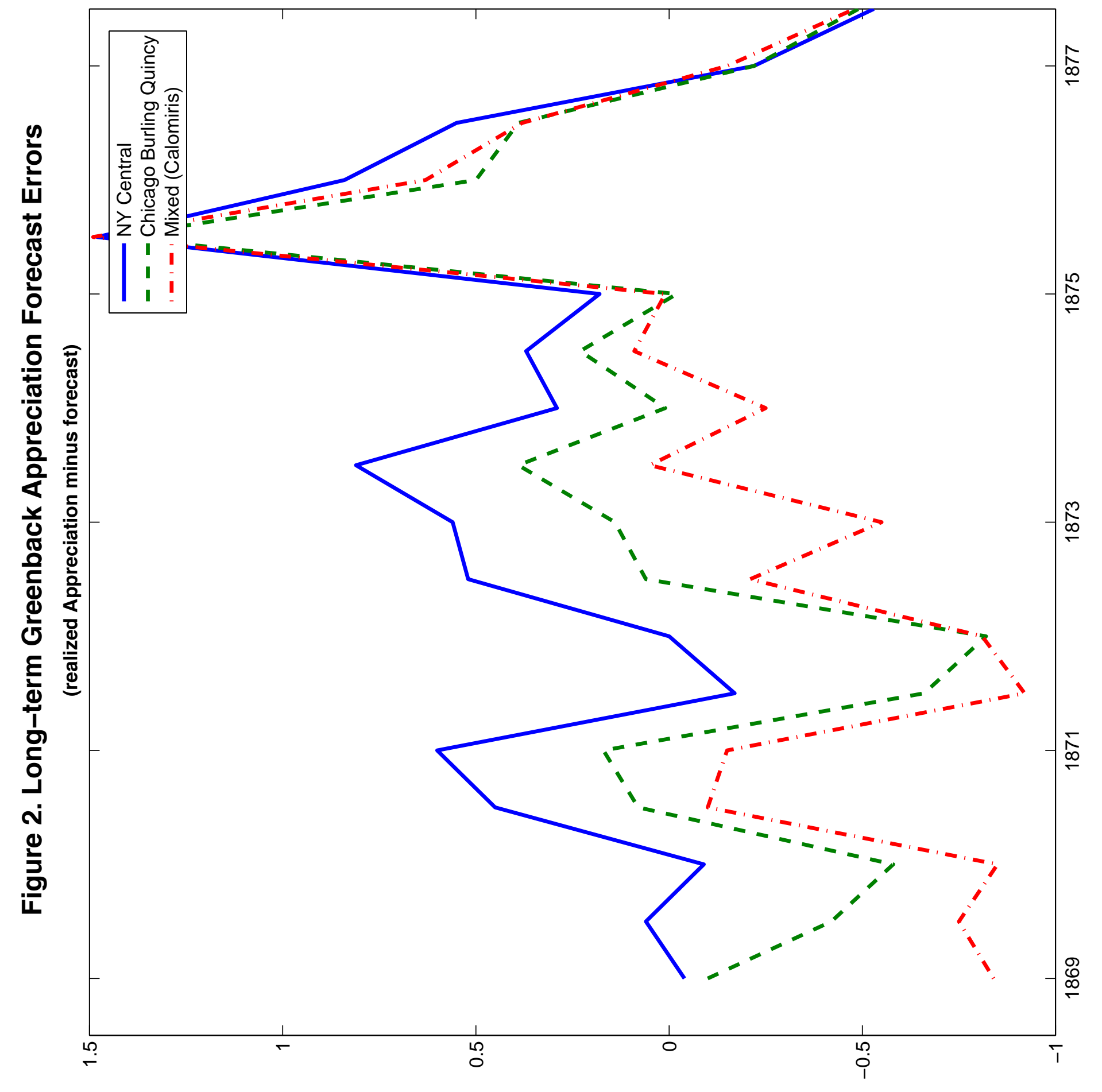



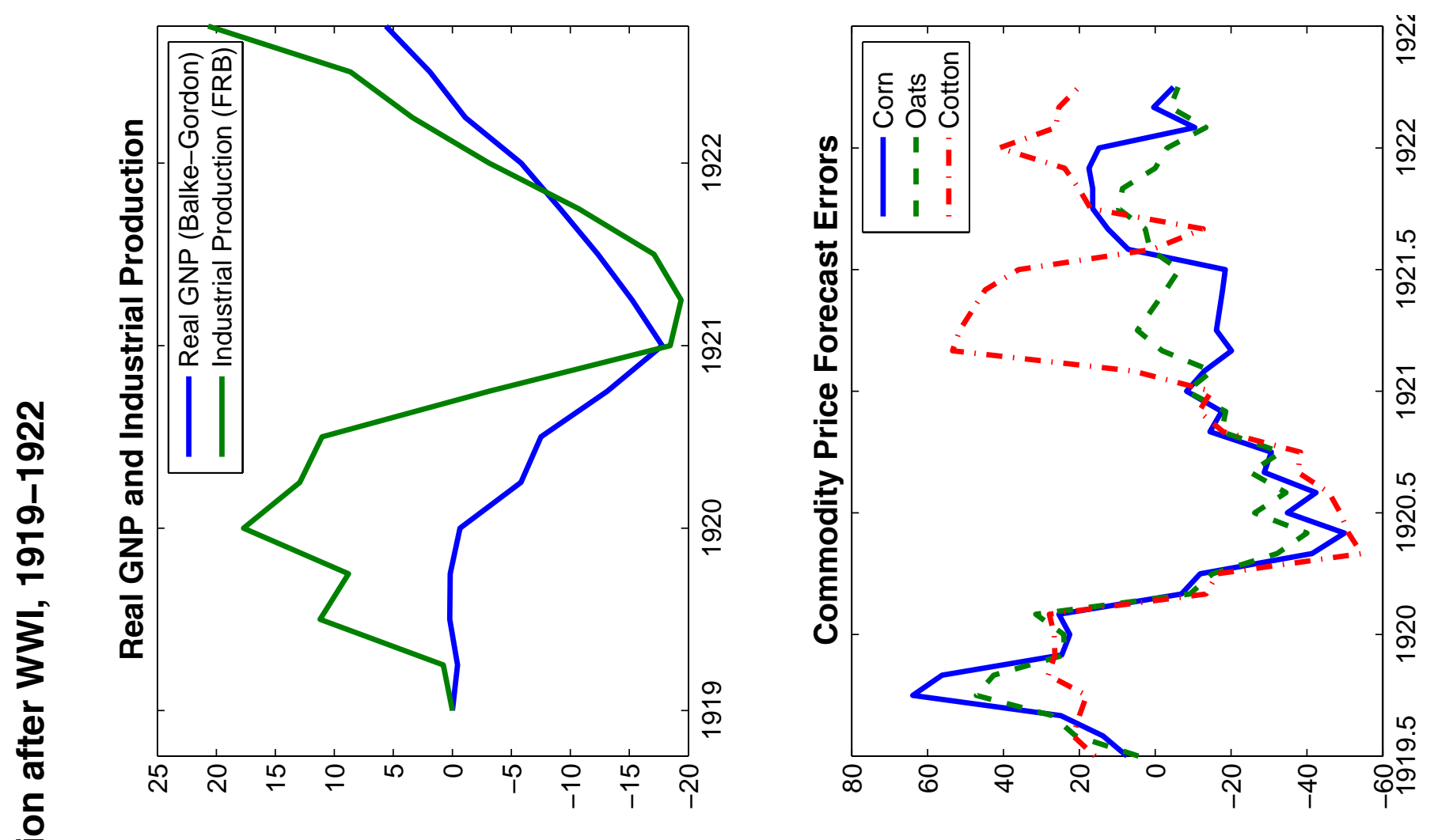

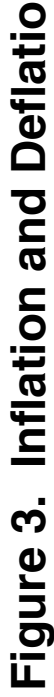
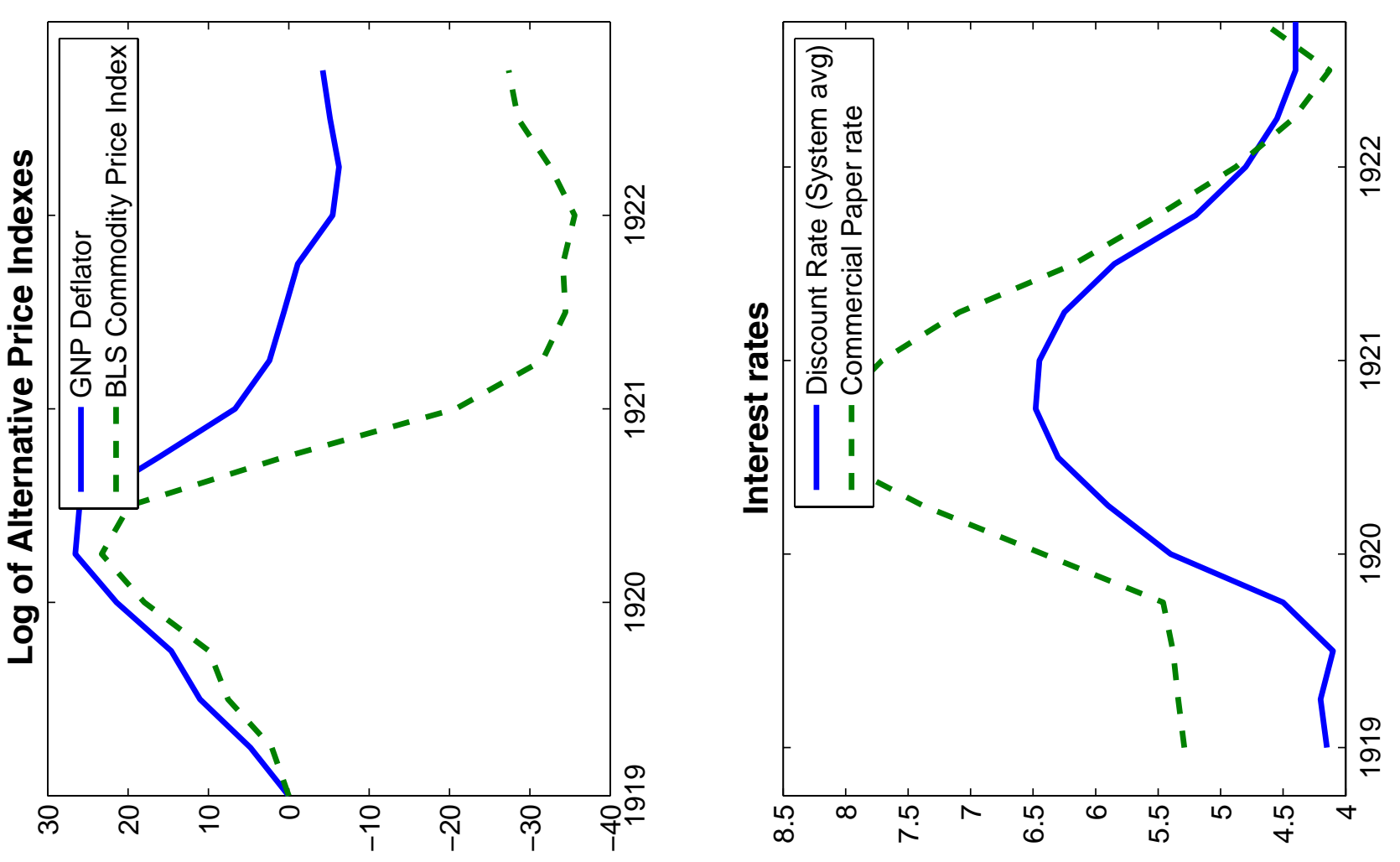

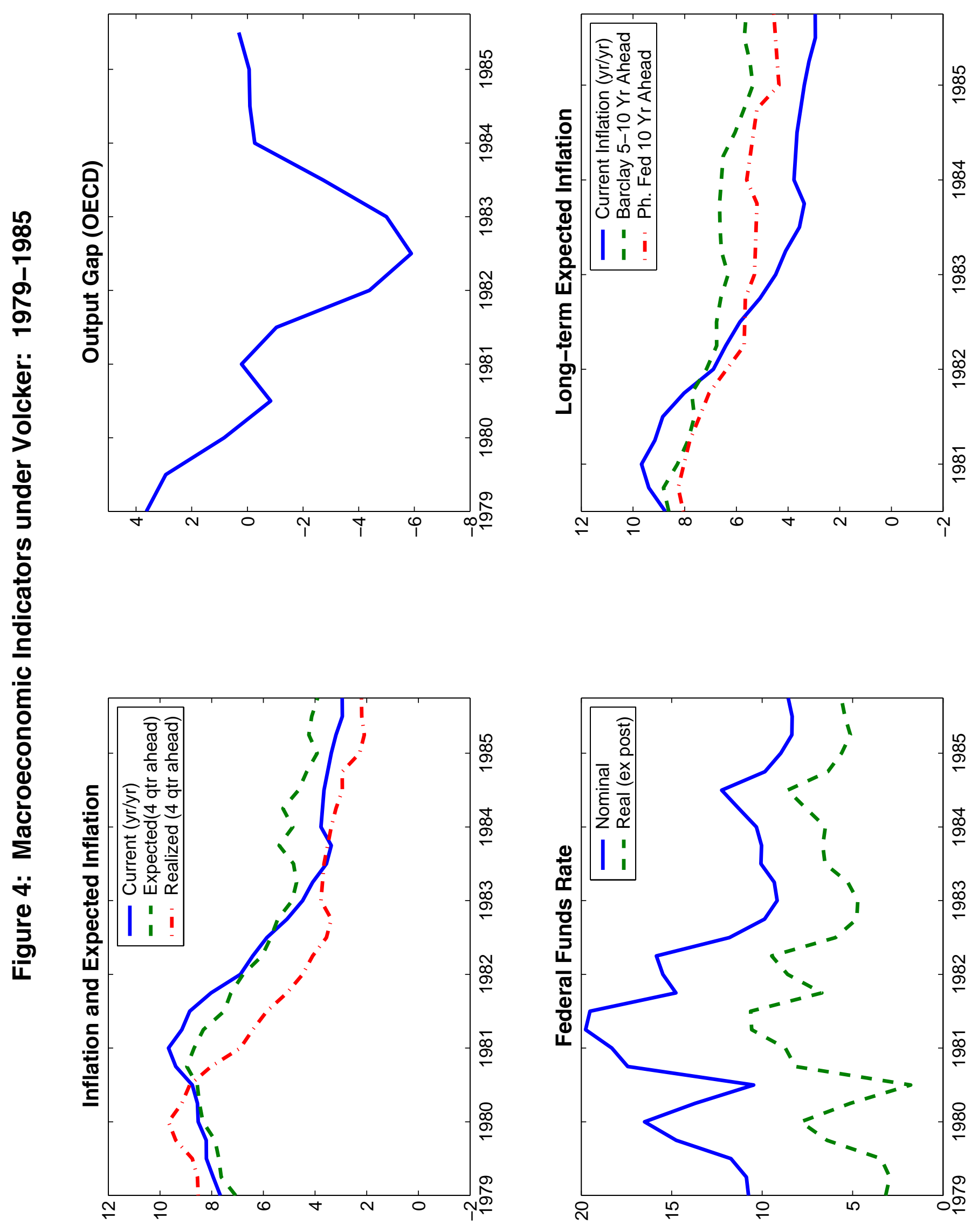

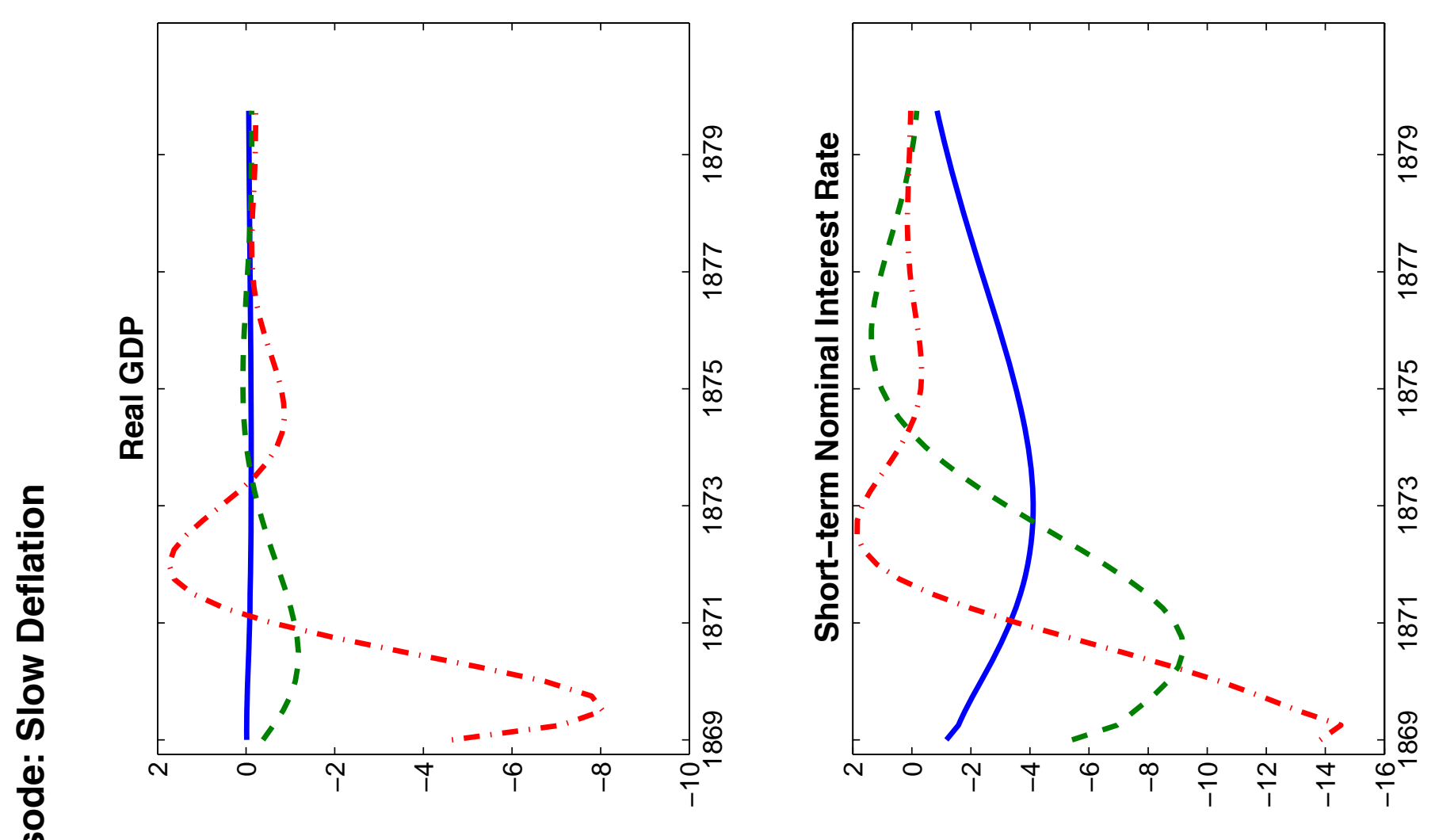

岁
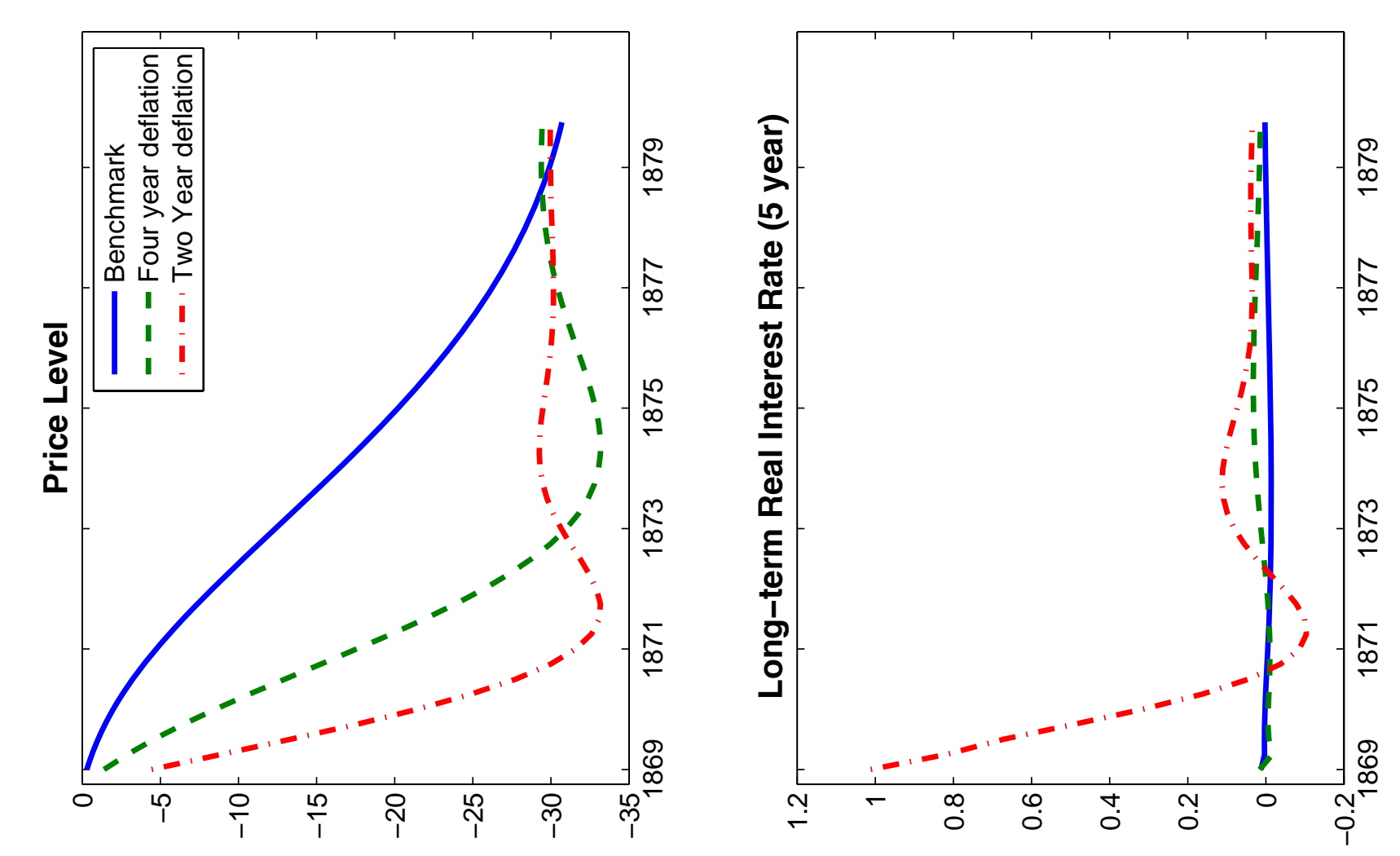


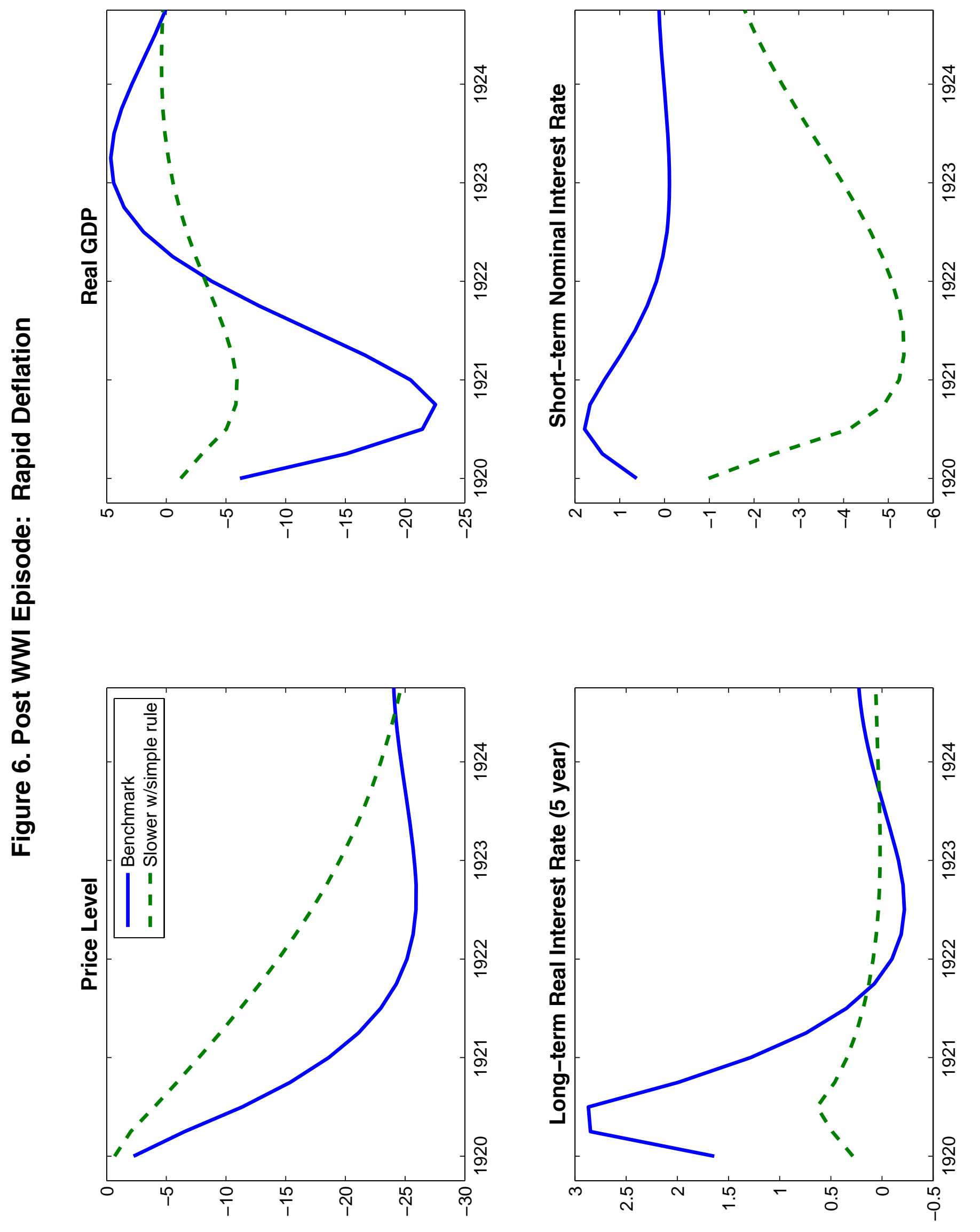




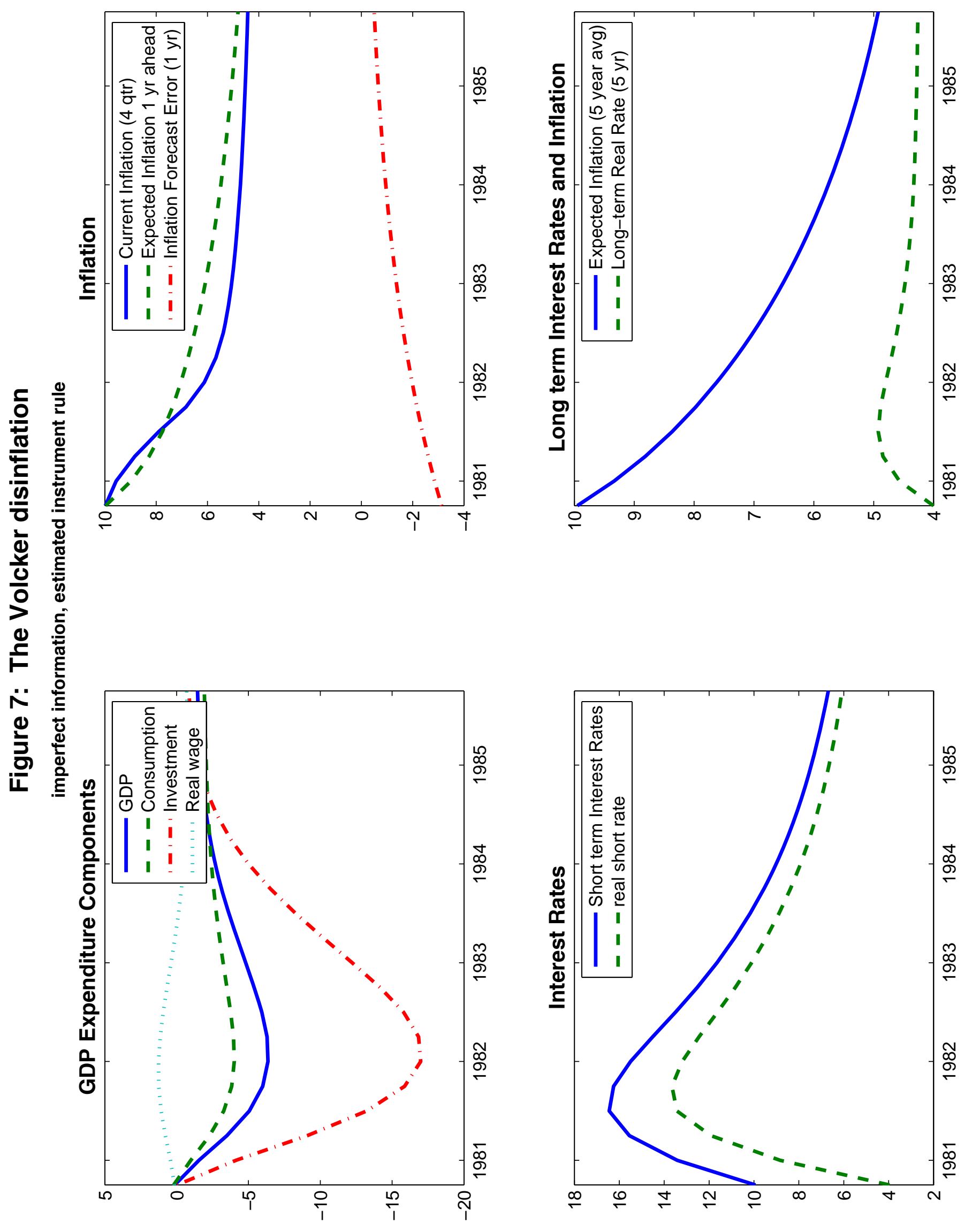




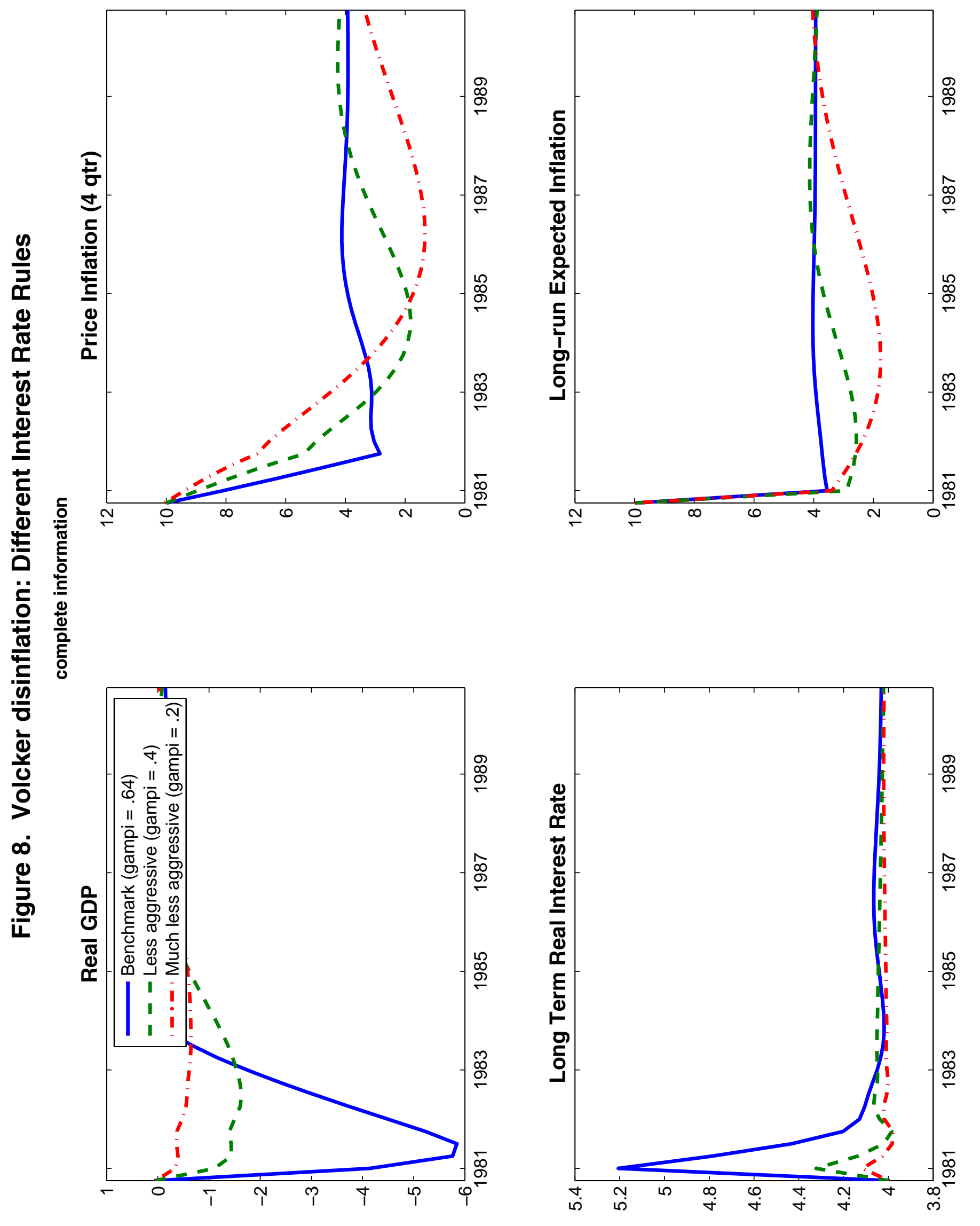



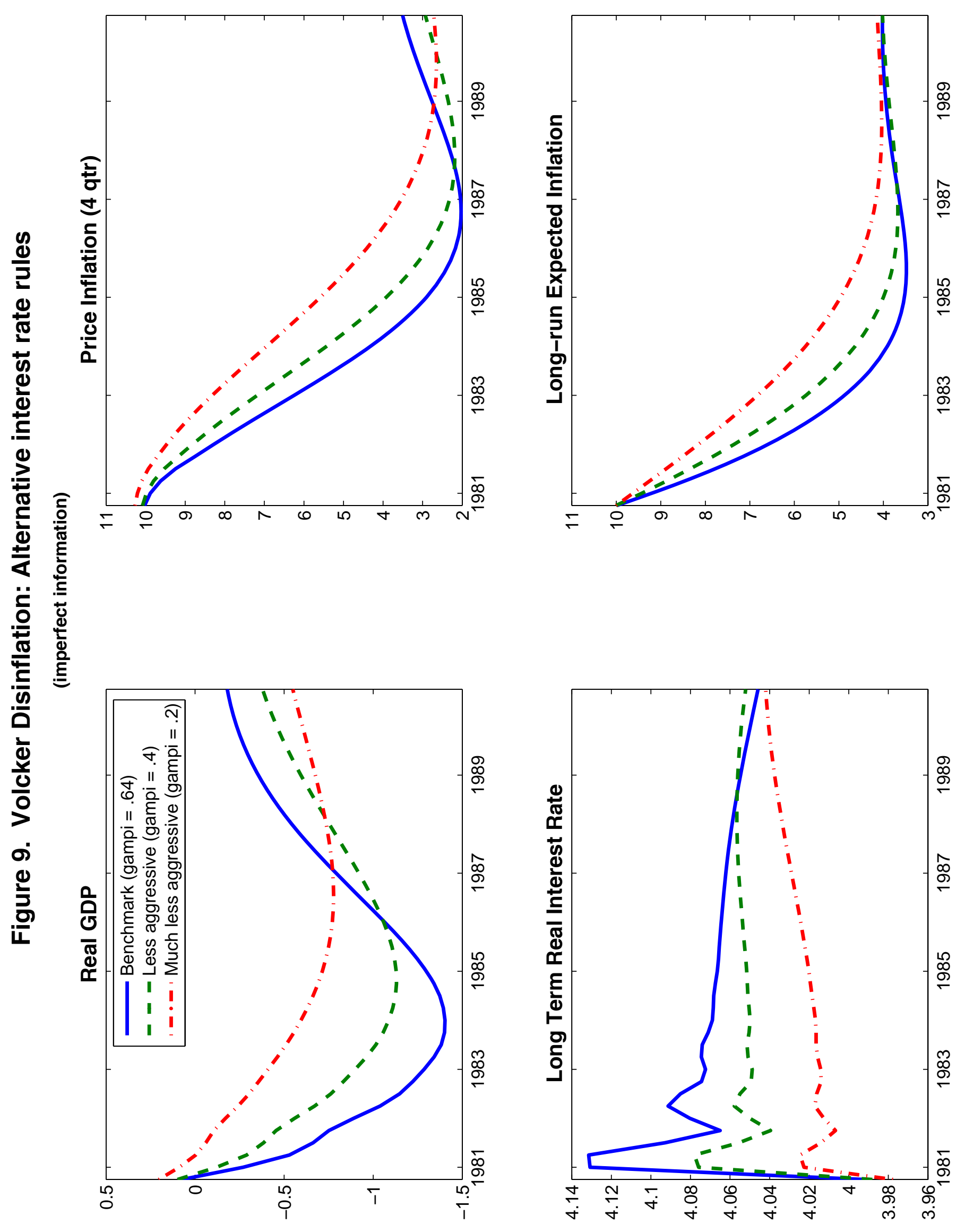


\section{CFS Working Paper Series:}

\begin{tabular}{|c|c|c|}
\hline No. & Author(s) & Title \\
\hline 2007/04 & $\begin{array}{l}\text { Michael Sonnenholzner } \\
\text { Achim Wambach }\end{array}$ & $\begin{array}{l}\text { On the Role of Patience in an Insurance Market } \\
\text { with Asymmetric Information }\end{array}$ \\
\hline $2007 / 03$ & $\begin{array}{l}\text { Michael Binder } \\
\text { Volker Wieland }\end{array}$ & The European Central Bank \\
\hline 2007/02 & $\begin{array}{l}\text { Francis X. Diebold } \\
\text { Kamil Yilmaz }\end{array}$ & $\begin{array}{l}\text { Measuring Financial Asset Return and Volatility } \\
\text { Spillovers, With Application to Global Equity } \\
\text { Markets }\end{array}$ \\
\hline 2007/01 & $\begin{array}{l}\text { Günter W. Beck } \\
\text { Kirsten Hubrich } \\
\text { Massimiliano Marcellino }\end{array}$ & $\begin{array}{l}\text { Regional Inflation Dynamics within and across } \\
\text { Euro Area Countries and a Comparison with the } \\
\text { US }\end{array}$ \\
\hline 2006/35 & $\begin{array}{l}\text { Christopher D. Carroll } \\
\text { Misuzu Otsuka } \\
\text { Jirka Slacalek }\end{array}$ & $\begin{array}{l}\text { How Large Is the Housing Wealth Effect? A New } \\
\text { Approach }\end{array}$ \\
\hline 2006/34 & $\begin{array}{l}\text { Giuseppe Bertola } \\
\text { Winfried Koeniger }\end{array}$ & $\begin{array}{l}\text { Consumption Smoothing and Income } \\
\text { Redistribution }\end{array}$ \\
\hline 2006/33 & $\begin{array}{l}\text { Siem Jan Koopman } \\
\text { Roman Kräussl } \\
\text { André Lucas } \\
\text { André Monteiro }\end{array}$ & Credit Cycles and Macro Fundamentals \\
\hline 2006/32 & $\begin{array}{l}\text { Rachel A. Campbell } \\
\text { Roman Kräussl }\end{array}$ & $\begin{array}{l}\text { Does Patience Pay? Empirical Testing of the } \\
\text { Option to Delay Accepting a Tender Offer in the } \\
\text { U.S. Banking Sector }\end{array}$ \\
\hline 2006/31 & $\begin{array}{l}\text { Rachel A. Campbell } \\
\text { Roman Kräussl }\end{array}$ & $\begin{array}{l}\text { Revisiting the Home Bias Puzzle. Downside } \\
\text { Equity Risk }\end{array}$ \\
\hline 2006/30 & $\begin{array}{l}\text { Joao Miguel Sousa } \\
\text { Andrea Zaghini }\end{array}$ & $\begin{array}{l}\text { Global Monetary Policy Shocks in the G5: A } \\
\text { SVAR Approach }\end{array}$ \\
\hline
\end{tabular}

Copies of working papers can be downloaded at http://www.ifk-cfs.de 